


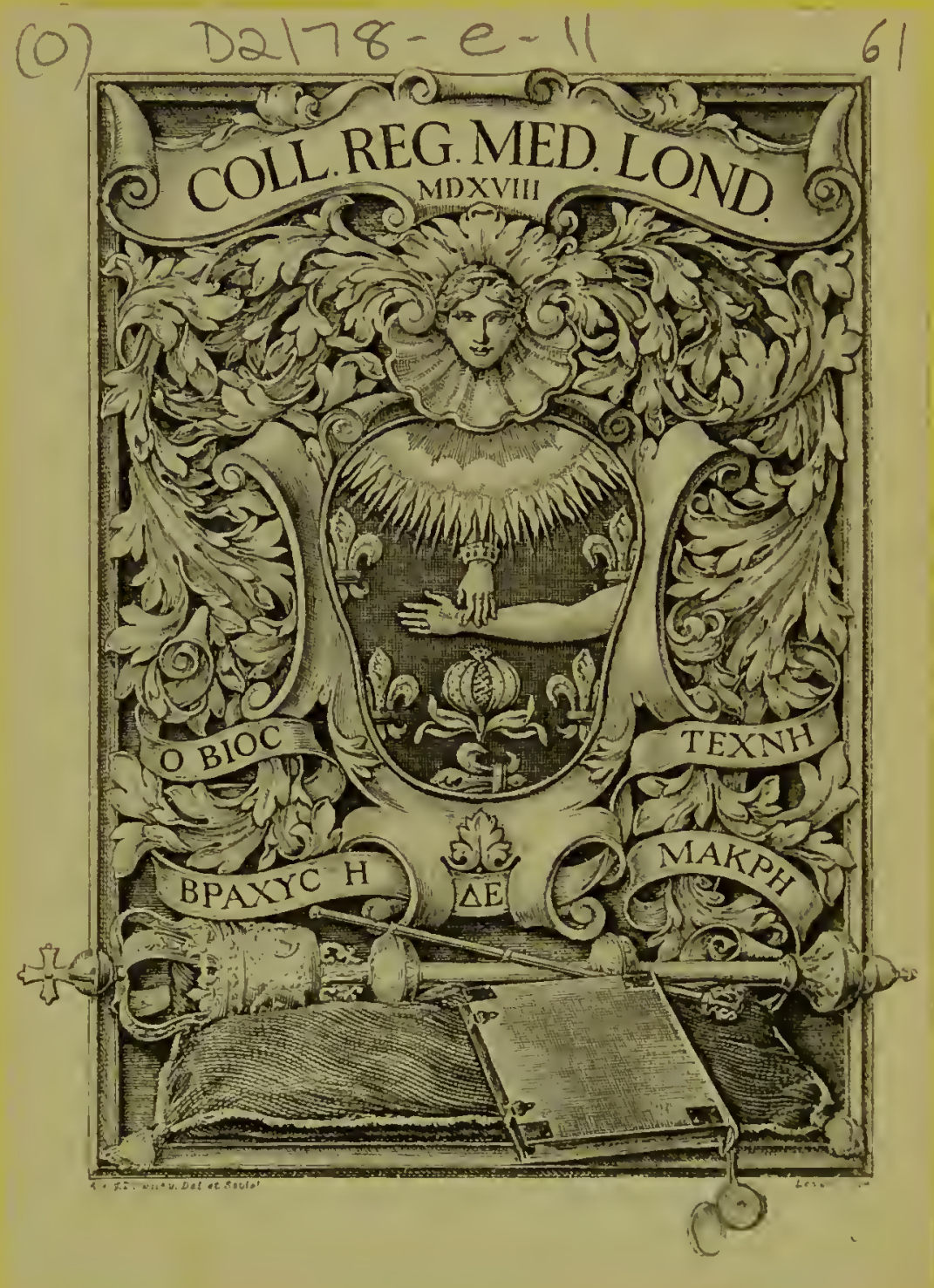



$4)$ 
TIIE RELATIVE

\title{
INFLUENCE OF THE SEXES
}

\author{
CONSIDERED,
}

\section{In Reference ta Hropagatiour,}

AS IVELL IN

MAN AS IN THE LOWER RANKS OF ANIMALS.

\section{BY JOHN WRIGHT,}

MFMBER OF THE ROYAL COLLEGE OF SULGRONS IN LONDON.

Desine quapropter, novita te exterritus ipsâ, Hxspuere ex animo rationem; sed magis acri

Judicio perpende: et, si tibi vera videntur,

Dede manus; aut, si falsum est, adcingere contra.

Lucretius.

\section{LONDON :}

PRIN'IED FOR THE AUTHOR.

1842. 



\section{PREFACE.}

As undertaking which shall have, for its object, a furtherance of the interests of society, needs not an apology for its introduction. Such is the character, and such the pretensions, of the little work which I now submit to the consideration of those who may be seeking instruction on the several questions that come within its range. By education, no less than by native bias, was I led, many years ago, to inquire into the diversities of constitution, and the extent to which they are influenced, by variableness of circumstances, in connection with generative intercourse. Modern physiology, though abounding with every conceivable theory, on the subject of generation, in the abstract, was found almost silent in its application to my purpose. Nor could I largely avail myself of the doctrines propounded in the ancient schools of philosophy. Valuable apothegms presented themselves; but, as a system, I could discover nothing that would bear the test of rigid investigation. Even the authority of Epicur'us, which, in many respects, is greatly to be relied on, proved 
to me a most formidable stumbling-block, on a point of vital importance, until reconciled with the construction which experience, at length, enabled me to provide. After toiling long and fruitlessly, in retirement, I resolved to depend mainly on the opportunities which medical practice should afford, for noting the peculiarities of individual temperament, - the mode and degree in which such peculiarities influence the sexes towards each other,and the effects produced upon the moral and physical condition of their offspring. At the same time, I undertook a series of experiments, in the breeding of cattle, pigs, fowls, and rabbits, with a view to learn how close an analogy subsists, betwcen man and other animals, in the immediate, and ultimate, tendencies of the reproductive passion. This part of my engagement, I need hardly remark, had a special reference to the improvement of whatever breeds I should adopt : and, perhaps, I cannot confer a greater service on those who may, hereafter, be disposed to emulate the task, than by presenting them with a cursory outline of my procedure. The rcsult will be seen to justify a remark addressed to me awhile ago, by a very great and good man,* that if a gentleman, turning his attention to farming

* The Right Honourable Earl Spencer. 
late in lifc, attempt such an enterprise, it might bc considered next to a miracle, if he did not fail.

In the first instance, I deputed a jobber to provide me with a few well-bred calves. A pleasing exercise, I thought it would afford, to watch thcir growth ; and shortly I had an opportunity of gratifying my desire. The man of business invited my attention to some, recently weaned, which had becn brought from the hilly districts of Derbyshire, and which he declared he could strongly recommend for hardiness. The prevailing colour (light blue, with black eyes and muzzles), uninitiated as I was, appeared of very doubtful propriety; yet I could not withstand the repeated assurance that it constituted the proudest feature in the breed. He wished particularly to sell them to me, because he knew whence they came, how they were bred, and he could, morcover, at any time, buy them of me again. So I gave him $£ 4$. 10s. each for starvelingsany one of which I could have conveniently carricd home. They would have been $\mathfrak{E} 5$ eacli, he said, to any body else. This was at the commencement of winter; and having folded them in a spacious yard, behind my house, until the following spring, at a considerablc expense, in the purchase of hay, turnips, and bran, without witnessing a corresponding improvement in the carcasc, I sold them, each, 
for a few shillings less than they had originally cost me. Nothing deterred by this unexpected discomfiture, I applied myself still to the work, but witl a determination, henceforth, to entertain none that should present the colour of the first lot. I was soon informed that a milkman, named Priestley, had a good red and white cow-calf, out of a favourite beast, for which he wanted a kind master. It was what, in the midland counties, is often designated a "spawny calf"-a more exact definition of which will be found in a subsequent part of this little work. But I may here observe that it was of uncommon length, and "up-standing" too, as the jobbers say, and only required to be proportionably thiclened, to make it represent a full grown beast. Indeed my wife, unaccustomed as she was, at that time, to regard animal organization, in reference to function, could not help exclaiming, when first shown it, that this was the chief, and, in her judgment, by no means an unimportant desideratum. Milk was purchased for its use, until a cow in full profit could be obtained; and, that the provision, thus made, might not be extravagantly appropriated, another calf, exceeding in length even that which already graced my establishment, was bought in. "Lizard" was the name employed to distinguish it from the former'; and, as it happened to combine, 
with other advantages, the attributes of the ruder sex, I contemplatcd, at no vcry distant period, a still closer affinity between the pair. An act of insubordinacy, however, on the part of "Lizard," presently led to an abandonment of the design: for, concciving, one day, a wish to do violence to the persons of myself and one of my children that was standing near me, he proceeded, forthwith, to thc execution of his purpose-the consequence of which was a speedy disinheritance of the privileges of his sex. Eventually these animals werc disposed of, as unworthy of the generous fare they had received.

I now began to discover my ignorance in the elementary duties attached to my province. I knew not the distinction between a good, and a bad, animal, and might well, therefore, be unfortunate in my choice. To supply this defect, I matriculated in the best practical school ; and, for many years, endured the opprobrium of an association with dealers, and others of like character, who swell our cattle markets with their presence. Scarcely a fair, or public sale, of interest, occurred within twenty miles of home, at which I was not to be secn; at the samc time that my private operations wcre being condueted, to as great an cxtent as was compatiblc with my means.

Beyond attaining to a knowledge of the indivi- 
dual and relativc mcrit of the sevcral classes of animals to which my observation was directed, an attendanec, on the oceasions just refcrred to, did not enablc me to proeeed. I had still to explore the way to improvement; and very naturally turned to sueh works as professed to entertain the subject. From them, however, I eould reap little instruetion. They appeared, for the most part, to have been writtcn by practical farmers, who laeked both the literature and seience required to impart efficicney to their tcaehing. Some authors I met with, who had eonfined themsclves to a rambling dissertation on the merits of their own herd: othcrs, venturing on higher ground, had eontended, with singular obliquity of judgment, that the varicties which thcy had becn pleased, rcspectively, to adopt, wcre susceptible of higher cultivation than the rest. Few had dared to grapple with general principles-to argue that, ceteris paribus, all equally admit of improvement, and that, thercforc, wc have only to consult the soil and climatc of whatcver locality we inhabit, with a view to dctcrmine the sizc we shall adhere to, to succed, by the application of general rulcs, in perfecting the carease. Mr. Cline attempted to accomplish thus muel : but he proved nothing; and the cxtravagant character of some of his aphorisms, has tended to impair the credit duc to his 
performanee in the main. It is a humiliating fact, that notwithstanding the wealth, talent, learning, and extreme faeilities enjoyed by the agrieultural interest, for the performance of such a task, there is not, at the moment I am writing, a work in the English language, embodying the principles of breeding, in aeeordanee with the present advaneed state of seienee. My inability to profit from sourees of this kind, suggested the alternative of a personal intereourse with experieneed brccders. The only objection that applied to the sehemc, consisted in the interruption my further absenee might oeeasion to the advaneement of professional interests. But this consideration lost mueh of its weight, from a reeollection of the faet, that, at no period, had what, in modern parlance, we term a discriminating public, imposed on me an excessive amount of duty ; and it was now but too evident that they never would: soon, therefore, I journeyed far and often, in the prosccution of my plan. And not unfrequently did it happen that the privations I endured on such expeditions, were of a eharacter to havc discouraged any one less passionately attaelied to the pursuit. Not to trespass wantonly on the indulgenee of my readers, I will adduee one or two instanees. In the month of Mareh, 1835, I determined to investigate the claims of the Devonshire 
eattle to the flattering representation given of them, in the Treatise, published under the superintendenee of the Society for the Diffusion of Useful Knowledge ; and having business to transaet in London, whieh eould very shortly be disposed of, I proeeeded by that route. The first day was consumed in reaehing the Metropolis, - the next in passing thenee to Exeter, where I arrived late at night, after travelling, in two days, on the outside of coaehes, a distance of two hundred and ninety-seven miles, in unmitigated pain, arising from obseure abdominal disturbanee, of long standing, and eounter-irritation, established for its cure. The judges were, at that time, on their cireuits, and I could obtain no aeeommodation at either of the large inns in the town. A fellow, after the class of those to be found often in the neighbourhood of such establishments, tendered his services to eonduet me to an abode. Five minutes' stay, however, within its walls, served to convince me that both my person and property would be endangered by remaining; and, in angry mood, I rushed, unceremoniously, into the street, in search of a more hospitable roof. Whilst treading hastily along, and observing the previous bustle and anxiety of the day merge into the growing stillness of night, I was deploring the infatuation that had brought me thither, when, on a sudden, my revery was interrupted by the separation of two elderly 
men, at the door of one of the parties. I mentioned my condition to the resident of the house, who, liappening to be an innkeeper on a limited seale, was glad enough to entertain me. On the following morning I proeeeded by coaeh to Barnstaple, in time for a quarterly eattle market, to be held there the next day. The business of the market having been coneluded, I rode a pony over ten ol' twelve miles of bad road, to the house of Mr. Davy, of North Molton (a man of pleasing frankness and intelligence), with whom I passed an evening in profitable eonversation. Another day was spent in the inspection of Mr. Davy's beautiful herd of North Devon eattle, and in visiting Mr. Tapp, of Twitching, and the Messrs. Quartley, of Molland, for the same purpose. At night I reposed at South Molton, intending to proeeed by the mail, that should pass through, the next morning, on its way from Barnstaple to Bristol, in my return home. I rose by 6 , a.m., and the mail not being expected till 9 o'elock, I slung my carpet-bag, weighing, with its eontents, and an upper eoat, for which $\mathbf{I}$ had now little oeeasion, 17 lbs., aeross my shoulder, and walked leisurely on to North Molton, for the sake of eontemplating, from a hill in its immediate vicinity, a spot renowned for the excellenee of its eattle, and onc too, where I had recently experieneed 
the greatest possible kindness. After feasting my soul awhile in meditation, I wandered along a circuitous path, that led me into the Bristol road; and now I diseovered that a walk of four or five miles had served to advanee me about one and a half, on my way home. Presently the mail came up, and lo! it was full. I had, therefore, the option to return to South Molton, where I must have remained unoccupied till the following day, or journey in a direction that should afford me no refreshment within the next fourteen miles. Not liking to retrograde, I pursued my way, and, by noon, found myself eomfortably seated at the Reindeer, near Bampton-having completed about eighteen miles, under the grievous burden already mentioned, without food. Ten or twelve miles, if my memory serve me aright, yet lay betwixt me and Wiveliscomb, whither I was anxious to arrive that day. Before doing so, I grew very tired; when observing a man of professional exterior approach, who was riding in the same direetion, I begged that he would, for a few minutes, relieve me of my load. Thinking, probably, that so great an aet of eondescension would ill accord with the dignity of his station, he refused; and I, feeling invigorated by the repulse, experienced little subsequent fatigue. Having reached Wiveliscomb, I 
passcd the night therc; and, hastcning on to Bristol the next day, arrived in time for the mail to convey me thence to Birmingham, by night; and at noon, on the eighth day, I was with my family, aftcr travelling six hundred miles (five hundred on the outside of coaches), and that, too, under the pressure of unceasing pain.

When, in pursuit of this recreative study, I have been able to command sufficient time and strength, my excursions have generally been performed on foot, as conducive alike to meditation, and an economical expenditure of money. And not uncommonly has a similar disappointment to that which I encountered at Exeter, befallen me at the close of a long day's journcy. At four o'clock one morning, in the latter part of September, 1835, I set out for Chesterfield, where the Derbyshire Annual Agricultural Meeting was about to be held, intending to proceed thence to Wiscton, for the purpose of enriching my stock of information, if possible, with some facts, derived from a survey of Earl Spencer's short-horns. By II, a. m., I had accomplished the first part of my undertaking; and after spending two hours in the show-yard, I resumed my walk in the direction of Worksop. In the village of Staveley, I had the good fortune to come up with 
a gentleman, who was driving thither, and who gencrously invited me to accompany him. I now thought there was a prospcet of reaching Barnby Moor that night, and immediately, on leaving my friend, procecded along the road he had described, through Bilby, and arrived where I anticipated the comfort of repose, before 7 o'clock. Whether the honour conferred on the posting establishment in Barnby, by her Majesty (then Princess Victoria) having becn graciously pleased to sleep there, on her way to Doncaster, shortly before, had rendered its inmates insensible to the necessities of so mean a subject as mysclf, or whcther it was the custom of the house to refuse an entertainment to pedestrians, I know not. But this I know-it was denied to $\mathrm{mc}$; and, at the instance of those with whom my intcrvicw was conducted, I subscquently applied to another establishment in the same place, where, for my consolation, I was assured that they lodged none but coachmen and guards. This negative, like the former, was accompanied with a friendly intimation that I should most likely be able to find an asylum clsewhere-that is to say, if I would incur the trouble of walking to Sutton. The proposition was, in some measure, acceptable to me, since that village lay a mile nearer the cstate I was about to visit. Still I could hardly forbear to re- 
proach myself for having risked so much bodily fatigue and mental torturc, without the lcast probability of realizing cither an immediate or prospective advantage. Already had I walkcd nearly forty miles, to say nothing of two hours' exercise in Chesterfield; and had partaken of no food since my breakfast at Mansfield, excepting some brcad and cheese, the best fare the good landlady, at whose house I rested awhilc, in Staveley, could provide: and I was both hungry and tired. While musing on the horrors of impending starvation, the village I was in quest of appeared in sight; and thinking it advisable, without regard to the occupation of its inhabitants, to make my case known, wherever therc should seem to be indications of comfort, I did so. Onc had not a spare bed,another had, but it had bcen so long out of use, that my safety would unquestionably be endangered by sleeping in it. Others declared that to be a cross-country road, in which men of honourable pursuits were nevcr benighted, and affected to regard my application as a marvellous piece of daring. Prudence forbade me to tell them that I had money, whercwith to discharge every obligation, lest $\mathbf{I}$ should sharc the fate of a late rcsidcnt of that village, who had been murdered for the sakc of a fow pounds he had with him. At length I 
entered a public house, at the farthest extremity of the place, and was making my best appeal to the feelings of its inmates, when a good-natured man, who listened attentively to my story, observed that, if I would wait till he should have emptied his cup, he would engage to procure me a lodging at Lound, another mile yet on the road to Wiseton. With a promise of a few more "cups" when he should have accomplished his purpose, we started off together; and soon he introduced me to a matronly lady, who, after surveying me with an air of singular curiosity, avowed her willingness to serve me in the best way she could. Having administered to the demands of hunger, she conducted me up a crazy staircase, into a three-bedded room, appropriated, ordinarily, to the use of two grown up sons, and an elderly man who lodged with them. To have demurred would have been ungrateful, since any accommodation within doors, was preferable to the fields or highway; but never shall I forget the inconvenience to which I was subjected. The bed set apart to my service was so unaccountably short, that, though commanding no greater altitude than five feet nine inches, I could not stretch myself out at full length, even when observing some degree of obliquity. In this state I lay, unable to sleep, and afraid to request that the 
old man, whose stockings emitted a most noisome stench, would be pleased, for my sake, to draw them on his legs again, till the light of approaching morn should invite me to a purer air. Shortly before 6 a.m. I arose, and walked to Wiscton Hall, where I had the good fortune to meet his lordship's bailiff, commencing the routine of his daily labour. After inspecting, with as much minuteness as time and opportunity would allow, what, perhaps, might justly be deemed an unrivalled herd of cattle, I returned to Lound, at a somewhat unseasonable hour, for breakfast: then walking to Worksop, in time for a coach that should pass through that town, on its way to Nottingham, I got home in the evening of the same day.

From the preceding detail, may be formed an imperfect idea of the labour I have sustained, in the investigation of this subject. A very natural inquiry arising out of such consideration, is the amount of verbal instruction I have been able to obtain, in reward for my trouble. Little more, I regret to say, than has been derived from books. One portion of the agricultural community, numbering some of our wealthicst farmers, and the officials of noblemen and gentlemen, I havc usually found difficult of access, as indeed are men of importancc in cvery sphere. Them I have hardly dared to 
address interrogatively; and when presuming, occasionally, on their indulgence, disappointment has awaited me. Another section, including those, in part, whose attention is more immediately and successfully engaged in the practical department of the subject, have shown a readiness to exhibit their stock; yet on all questions, involving the modus agendi, they have preserved a studied silence. A third party, no less distinguished as practical breeders, have been free to communicate what they have known, but for want of clearness of conception, they have been unable, except in few instances, to dispose advantageously of even facts. My undertaking throughout, therefore, has been one of extreme toil and perplexity; and whatever may be the defects observable in this attempt to make it available to the interest of others, I am fairly entitled to the sympathy of my readers. Let it not, however, be inferred from this expression, that I am anxious to elude the test of criticism. I court it, as the only means afforded me of arriving at a just estimate of my own performance. One indulgence only do I crave-a correction of the sense, where obscurity or error shall be detected; so that, in the enjoyment of such counsel, my advantages may be multiplied, and truth eventually prevail. Unfeignedly do I protest that, in assuming the character of an autho- 
rity, I have no morbid ambition to consult - no personal considerations to promote. I have always thought it desirable to obtain instruction for the farmer, at the hands of those who are professedly ellgaged in agriculture; and have looked to that source, during the last three years, for contributions to the subject on which I have at length ventured to write, in pursuance of the example of a nobleman, to whom all classes are deeply indebted for his services, in the common cause of patriotism.* I have looked in vain : and believing that I could, in part, supply the deficiency, I have proceeded on the somewhat novel system of generaliaation; and have, in so far, I hope, adapted my labour to the prevailing wants of society. Still am I not without apprehension that, in following the coursc which philosophy has dictated, I shall subject myself to animadversion. It will be alleged by two classes, that comprise, unfortunately, the chief bulk of my species-those, on one hand, who have yet to discover the infirmity of their own nature; and those, again, who, having attained to such knowledge, affect to believe that 110 analogy can be drawn between animal propensities, as developed in man,

- See Lord Speneer's paper on the selection of inale animals, in the breeding of eattle and sheep, in the Journal of the English Agricultural Society, vol. i. page 22. 
and in the subordinate ranks of the ereation-that I have attempted to degrade the noblest work of God to a level with the brute. My defenee is simple and easy. Sin has made humanity what it is : I have taken Nature for my guide-" nothing extenuating, nor setting down aught in maliee."

With this apology for the general tenour of the work, I beg to observe that there is one argument eontained in it, whieh, though strietly orthodox, might, if published, give pain to the mind of an individual whom I am bound in duty to revere - and whieh I had not anticipated, until the entire edition

- had been struek off. On this aeeount it is my intention to limit its eirculation to those, in whose hands it will not be likely to sustain perversion.

Having, originally, designed to instruct those, for the most part, who have not enjoyed the advantage of a liberal education, it has been deemed advisable, when, with propriety, they eould be introdueed, to accompany the several elassieal passages with appropriate translations.

21, High Pavenent, Notringham.

May 20, 1842. 
RELATIVE INFLUENCE OF THE SEXES CONSIDERED.

Much has been said by agriculturists and others, with a view to impress upon the minds of those whose province it is to breed cattle, a conviction of the importance attachable to good males in the perpetuation of their several species. It is my object, in this work, to bring from the varied sources of information to which $\mathbf{I}$ have had access, such facts and reasoning as shall place the subject, if possible, in a more inviting and intelligible light than it has hitherto presented. To do this it will be necessary, in the first instance, to consider the relative character and disposition of the sexes.

Throughout the animal kingdom, it is observable that nervous vigour, from which strength, courage, and all other physical attributes, proceed, is more freely bestowed upon males than females; and that this constitutional difference gives, for the most part, a stamp of activity to 
the former, and of passiveness to the latter. It is only under peculiarly exciting circumstances, as when charged with the protection of their young, that Nature awards to females a temperament approaching to that of their male consociates. In no sense, perhaps, is this characteristic distinction more palpable than in the influence of physical love upon the sexes. Take, for example, a male of our own species in the full exercise of a generative faculty, and without that restraint which morality very justly imposes: he seeks to gratify his passion for selfish purposes; no sentiment, in its best construction, identifies him with propriety: the maid, the matron, the virtuous and the dissolute, the cleanly and the dirty outcast, are alike acceptable to him ; and, if none be available, he skulks into solitary intercourse with his feelings, and practises the vice of onanism. His disposition, still further outraged, prompts him to ravishment and other personal abuses, which the Christian shudders to contemplate. Physical love, therefore, in our own sex may be said to exist, for the most part, in an active and selfish form. Now contrast it with a kindred faculty, as exemplified in woman. Less powerfully influenced by nervous impulse, she acquires the art of self-government in so far, that neither the presence of stimu- 
lating fluids, nor of men, offers her an inducement to become actively regardless of the obligations of her sex. She waits to have called forth a latent disposition to sexual commerce, by the personal attentions and entreaties of man; and if the wiles of the seducer betray her into sin, she yields assent for his gratification more than for her own. She is persuaded to believe that her indulgence of the individual addressing her is indispensable to his happiness,-and her acquiescence, whilst originating in amiableness, is made, for want of yet more self-possession, to constitute a crime. In marriage, too, a like difference of feeling and of action equally obtains, though subjected of course to that modification which individual circumstances must, at all times, to a greater or less extent, necessarily involve. Physical love, then, in woman is distinguishable from that of man by its passive and relative character ; and any deviation from that law of nature which makes it such, as witnessed in prostitutes for instance, is incompatible with the economy of the uterine system, and forbids conception.* Hence I argue that no

* This doctrine constituted a prominent feature in the Epicurean system of philosophy, as we lcain from Lucretius. T'o quote the original text would, I fear, be only to embarrass the general reader; and a translation, unfortunately, wonld subject me to the charge of indelicacy. The scholar may find it by refering to Lueretius, Dc Rerum Natura, lib. iv. v. 1256. 
greater injustice can be inflicted on the sex than that which they not unfrequently encounter from pseudo-philosophers and libertines, who ascribe to them less control over their animal passions than is maintained by ourselves.

Observation and analogy will justify me in declaring that the cow, sheep, and sow, when in season, hold the same passive relation to the bull, ram, and boar, which woman does, at almost all times, to her favourite of the other sex. And there being little inconsistency in the operations of nature, we observe in females generally what well agrees with the comparative inactivity of their uterine organs, in a successful copulation, a greater laxity of fibre throughout, than we recognize in males of corresponding character.*

* This condition was strenuously insisted on by the earlier authorities as essential to success in the breeding of inferior animals. 'Thus Virgil, in allusion to mares, observes:

Ipsa autem inacie tenuant armenta volentes;

A tque ubi concubitus primos jam nota voluptas

Solicitat; frondesque negant, et fontibus arcent :

Sape etiam cursu quatiunt, et sole fatigant, Cùm graviter tunsis gemit area frugibus, et cùm Surgentem ad Zephyrum paleæ jactantur inanes.

But when connubial joys new passion fire,

Georg. iii. 129.

By famine tame the bride's intense desire.

From pampering food and gushing fount restrain,

Tire in the sun, and press along the plain,

When groans the bar'n beneatl the dusty flail, And the wing'd chaff light flics before the gale.

Soтния 
Where this distinction duly obtains between the sexes, their offspring inherits, most commonly, the general configuration of the male, at the same time that it blends the constitution and disposition of each parent, more intimately than would seem to be indicated by the physical outline. To what precise cause such result is attributable, it is difficult to determine. Popular opinion would refer it to superiority of vigour on the part of the male; but that supposition is discountenanced by the fact, that a change of moral circumstances is sufficient to give ascendency to the female. Observation, directed no less carefully to the habits of inferior animals than to those of mankind, assures me that the venereal passion, viewed simply in regard to its intensity, can in nowise lead to a solution of the problem. It must be considered in relation to the individual included in the embrace; and then it may be in excess, as observable in the healthiest males, or passive, as in a majority of females : the sex that most indulges in abstract voluptuousness - the one least enamoured of the other's charms, is always most faithfully represented in the person of the offspring.

This I will now proceed to illustrate, beginning with an alliance which seems best to harmonize with the original intentions of nature; and thence 
advancing to the more subtle forms of association, with a view to disabuse the subject of the prejudice and difficulty with which it has heretofore been encumbered. First, then, I will entertain the case of a duly proportioned man, of nervo-sanguineous constitution (such as is commonly witnessed in the person of a butcher), in a matrimonial connexion with a woman of truly feminine character, who shall have accepted him in the capacity of husband, from a conviction that he is, beyond all others, entitled to her confidence and regard. Taking her estimate to be a just one, he will not be found in constant dalliance at lome, but will seek to provide otherwise for her comfort, and give evidence in his own animal propensities, of moderation in all things. Connubial intercourse, in its most delicate sense, will be regulated entirely by the liealthful suggestions of nature.* When the seminal vesicles shall have

Lucretius happily portrays the more solid enjoyment of those who thus fulfil the obligations of their sex, than of the libertine, who wastes his energies in fruitless love:

Nee Veneris fructu caret is, qui vitat anorem;

Sed potius, quæ sunt sine pœnâ, commoda sumit.

Nam eerte pura est sanis magis incle voluptas,

Quam miseris.

De Rer. Nut. iv. 1066

Nor are the joys of love from those shut out

Who brotal lust avoid; the pure of heart

Far surer pleasures, and of nobler kind,

lieap that the wreteh of lewd and low desires.

fioon. 
become loaded, his gratification will be sought, and then, almost of necessity, to promote his own personal interest and comfort. His wife, whose moral goodness is implied in the circumstance of her having married him from the purest motive that can influence the female lieart, and who, during the absence of venereal excitement, will have passed her time sufficiently requited with an assurance that her domestic attentions have been pleasing to him, will now so far sympathize with his wants, as to account it a privilege to supply them ; and whilst he shall be mainly intent on his own enjoyment, she will repose in blissful contemplation of his worth, and leave the task of modelling the foetus to himself. Allowing both parents to remain healthy and discreet, as I have here represented them, their issue will consist chiefly of sons, bearing a strong resemblance to their father, but exceeding him in robustness, unless he be remarkable for strength, in which case, the limit assigned to improvement will have been reached.

Descending again to inferior animals, I will introduce as close a parallel as can be furnished in the instance of an improved short-horn bull, and a light-fleshed milking cow ; and, as the objection that would have applied to the use of names in 
the former illustration (which, by the bye, is one of many examples I see around me), cannot be urged here, I shall remark that, in the summer of 1836, I bought in Nottingham market, of Mr. Mackley, then occupying a farm at Carlton, about three miles distant, a six-year-old cow for $18 l$, that produced in three days time, a cow calf, which I immediately disposed of. She milked well, as do most light-fleshed cattle, when feasting on a luxuriant pasture; and knowing that it would be hazardous to attempt to breed a good calf from her, whilst her constitutional energies were being thus actively engaged, I suffered three months to pass over before putting her to the bull. Her frame was at that time considerably attenuated, but it was not actually wasting. The secretion of milk had greatly diminished; and the food with which she was supplied enabled her to sustain the process, at the same time that the carcase was preserved in health. I put her to Mr. Wilkinson's Will Honeycomb; and on the 29th June, in the following year, nine days after the completion of the usual term of utero-gestation, she yielded a cow calf, exactly resembling its sire. The little animal was well provided with new milk, I confess, for some time subsequently to its birth ; but its allowance did not, by any means, exceed that 
which is commonly apportioned by breeder's to their young stock. On the 6th December, some time after milk in every form had been discontinued, she weighed over a very correct machine, 36 stones. By January 5 th of the ensuing year, she had increased to 42 stones,-by February 5 th to $46 \frac{1}{2}$. March 1 st she weighed 50 stones, - and on 31 st of the same month, $55 \frac{1}{2}$ stones. Soon afterwards she was turned to grass, and the scheme of weighing was consequently abandoned. During the two months that intervened between January 5th and March 1st, we had excessively cold frosty weather; and though protected by a shed, in some measure, from its severity, it will be noticed that her growth proceeded more slowly at that time than before the commencement of such weather, or subsequently. In six days under the four months, throughout which her progress was watched, she gained a gross weight of $19 \frac{1}{2}$ stones ( $14 \mathrm{lb}$. to the stone); and if the improvement realized in those six days be taken into account, the gross increase, in round numbers, may be said to have been 20 stones in four months, - an average of 5 stones a month, from the completion of the fifth to that of the ninth month of the animal's life.

Some of my readers may wish to know a little more of the history of this animal. I will, there- 
fore, briefly add that she was pastured on good land, during the summer of 1838 . In the winter of 1838-9 she was less indulged, the black leg, a disease allied to erysipelas in the human subject, occurring to a most frightful extent, from repletion, and arrested but by powerful cathartics, early and copious bleeding, together with two incisions of six inches in length, each, through the skin and cellular membrane of the arm on the milking side. In the spring of 1839 , with a view to check her disposition to fatten, I secured her a pasture on Beeston IIassocks, the worst I could find in the neighbourhood of Nottingham, where she remained until $J$ uly; and having failed to conceive a calf, I sold her to a jobber named Porter, for 25l. He disposed of her to Mr. Lyon, a dealer well known in the northern and midland counties, who declared to Mr. Wilkinson, myself, and others, that she was the best he had ever bought in his life. In virtue of this opinion he sent her to a friend, who, as often as she came in season, put her to his bull, for the space of two or three months; but she disappointed him, and he sold her, if I mistake not, to a gentleman in Oxfordshire, where, according to Mr. Lyon's report, a short time since, she quickly proved in calf. 
Suspicion will probably have arisen in the minds of some, that there was an inherent excellence in the dam of this heifer, not yet acknowledged, to account, in part, for the merit of her offspring. Her pedigree is known to me; and lest its non-insertion should be made matter of complaint, I will give it. At the sale of the late Mr. Champion's stock, when quitting, I believe, the farm he had occupied at Blyth, in this county, many years ago, a cow, named Bridget, then in calf by his bull, Aide-de-camp, was knocked down to Mr. Mackley for 30l., or thereabout. She might be said to be of respectable descent, Mr. Champion having purchased, at the memorable sale of Charles Colling's stock, in 1810, a heifer, called Magdalene, in calf by her sire, Comet, for 170 guineas, from which the best part of his cattle proceeded. I have, however, good reason to believe that $\mathrm{Mr}$. Champion, though a zealous, was not a very successful, breeder. $\mathrm{He}$ was an enterprising, generous man; but he could not comprehend the laws which apply to the animal functions, and somewhat failed in his pursuit. Nevertheless his sale attracted much attention; and it is not reasonable to suppose that a beast of much worth would have been suffered to pass into the hands of a bidder for so inconsider- 
able a sum as that of $30 l$. She brought forth a cow-calf, which, in contradistinction to the dam, was called Young Bridget; and from her, by a common bull belonging to Mr. Lacey, at that time of Colwick, now of Adbolton, near Nottingham, my cow proceeded. Young Bridget, when aged, was sold, in calf, to a Mr. Neale, in the employ of Mr. Walker, of Eastwood, for, I am told, $15 l$. Whatever importance may be attached by the lovers of pedigree to the animal whose history I have just given, I can assure them that her birth was never, with me, made a subject of much consideration. Scarcely a fair, or even a market, occurs in the midland counties, that does not contain many in-calf cows possessed of greater merit than fell to her share.

To explain the cause of so remarkably good a heifer as the one in question being found to result from sexual intercommunion of a first-rate bull with a comparatively worthless cow, reference must again be made to the law of sympatly. No other theory can avail us. We must recollect that the animal passions which influence us, as human subjects, we share in common with animals of a lower rank in the creation. 'The cow, as previously observed, was introduced to the bull under the happiest possible circumstances; and 
when she saw a much finer male than had been looked for, one whose like she had never before witnessed, she felt precisely as does a woman of easy virtue, who sighs and falls powerless into the hands of a handsome member of our own sex, so soon as an improper overture is made.* She became instantly absorbed with admiration of his

* For an identity of feeling, on the part of all animals that cuine under the influence of physical love, philosophers and poets have long contended. Virgil, whom Dryden has vigorously sustained, treats the subject un reservedly in tlıe following verses:

Omne adeò genus in terris hominumque ferarumque,

Et genus æquoreum, pecudes, pictæque volucres,

In furias ignemque ruunt: amor omnibus idem.

Georg. iii. 242.

Thus every creature, and of every kind,

The secret joys of sweet coition find:

Not only man's imperial race, but they

That wing the liquid air, or swim the sea,

Or haunt the desert, rush into the flame;

For love is lord of all, and is in all the same.

So also Lucretius, to whom Virgil was probably indebted for the argument :

Nec ratione aliâ volucres, armenta, feræque,

Et pecudes, et equæ, maribus subsidere possent.

De Rer. Nat. iv. 1190.

And Thomson, in a passage of inimitable beauty and pathos-too long for insertion here, but the purport of which may be gathered from the lines I have selccted-equally subscribes to this view:

'Tis love creates their melody, and all

'This wastc of inusic is the voicc of love,

That even to birds, and beasts, the tender urts

of pleasing teaches.

Seasons, i. 611. 
beauty, and consequently imposed upon him all the responsibility attached to the first grand formative impression. He was two years old, in the pride of health and condition, - a circumstance never lost sight of by a breeder of judgment; and regardless of individual attractions, he served her, as he would have done any other female of his species, that should have invited him, to gratify the irresistible promptings of voluptuous ardour.

That the subject may be fairly argued, $\mathrm{Mr}$. Berry's rationale, which may be instanced as the one most commonly received, shall now be heard. After remarking that the characteristic of a wellbred animal is that which identifies its ancestors for several successive generations with the peculiarities in constitution and shape which it is the object of experienced graziers to obtain in their stock, he proceeds to contend that " the ancestors of a badly-bred animal will probably have varied in every possible way, and therefore there will be no distinguishing characteristic in its family. It is consequently most probable that the offspring produced from a cross between two animals so circumstanced, will be more like the one in whose family there is a distinguishing characteristic than the one in whose family no sucli character- 
istic exists." Now if the ancestors of a badlybred animal have varied in every possible way, what comes of the adage that "like will beget like?" In few words, the characteristic of a wellbred animal is to be found in an assemblage of good points,- - that of an ill-bred one in an assemblage of bad points,-and unless my explanation of the most frequent result of a union of the two be admitted, we are driven to the necessity of arguing that, in a physical sense, a law obtains, the reverse of what we recognize in morals,where good and evil are associated, the former gains an ascendency. But to adopt this construction, in principle, it follows that an ascendency, once established, should, cceteris paribus, be pretty steadily maintained: whereas we have only to breed from the product of extremes, amongst themselves, as will hereafter be more circumstantially shown, to discover the futility of such reasoning.

It cannot be denied that, though the physical character of the offspring is conferred most frequently by the sire, there are many instances wherein it seems referable almost entirely to the female. Such may occur even in the history of parents whose union I have represented as conducive to an opposite result,--either accidentally, 
as when, in acknowledgment of female blandishments, the husband is induced to contract a generative intimacy, without the healthful incitement of a truly masculine desire,-or, as not uncommonly bappens, when a change of circumstances or of bodily condition supervenes on advancing life. The common reward, say, of toil and carefulness, is discoverable in an improvement of their estate; and wishing, perhaps, to employ their savings in some business that shall admit of being conducted by the wife, whilst her husband pursues his accustomed labour, they open a retail shop, or embark in the "public line." And now, indeed, conflicts with the world, to which she has previously been a stranger, gradually obliterate those indications of moral and physical delicacy which have won for her the esteem of a private circle, and a twelvemonth's exercise in her new calling exhibits her an altered woman. Grown haughty and sensual, she conceives possibly a secret fondness for another man, and regards her husband only for the grosser purposes to which he can be applied; whilst he, observant of the change, thinks to recover the favour he has lost by enacting the part of a suitor once again. He takes on more or less of a maudlin character,--defers to her in all things, and their 
future progeny consequently bespeak the impress of their mother, and consist, for the most part, of females. A further rigidity of character-and the masculine temperament is, in so far, acquired, as to unfit the subject altogether for breeding.

Now, what is thus being continually exemplified in our own species, occurs also amongst inferior animals. The cow I have already mentioned as the parent of an excellent calf, may be adduced in illustration of a reverse order of things, on being again put to the bull. She was one of high nervous excitability, as will be readily understood when it is stated that she had a bold staring prominent eye, and that, in attempting to handle her on the day following that on which she was purchased, and but a few hours before calving, she dcliberately walked through one of the best constructed dead fences I ever beheld, lacerating her teats most frightfully. She required to be kept, as do all females of that class in particular, in low condition, to preserve the feminine attributes in their integrity. I lost sight of this fact, and presented her once more to Will Honeycomb, fresh, and in a high state of generative excitement, having two germs fitted for impregnation. The bull had grown rather too fat-therefore, taking on some degree of passiveness, the "ruling passion" was 
hers, and in forty weeks' time she gave birth to twins exactly resembling herself, and died soon after of puerperal fever. Thus, it will be seen from this example, which will be found to correspond in its result with many like experiments, that where male and female of dissimilar character are coupled, a compound, partaking equally of the properties of both parents, does not commonly follow : nor do I believe that such can well happen under ordinary circumstances. And I derive no mean contribution to this theory, from the concurrent testimony of those who have attempted to commingle two distinct varieties of cattle. A cow of Scottish birth, say, is put to a pure Durham bull, until a calf of each gender is obtained: admitting that they intimately combined the properties of both parents, and thus furnished what might be termed a singleness of character, it follows that they should, when placed in sexual apposition, perpetuate their species in all undegenerate form. Experience, however, tells us that this is not the case : they mostly deteriorate. They may exhibit decided evidence of activity and predominance on the part of their sire in the intercourse that called them into existence; but still there will prevail some inherent and distinct characteristics of the dam, which admit not 
of assimilation. The parents being "aliens in blood," - so far removed from all influence of consanguinity as to be recognized only as individuals of the same species, there is a distant approach, in their reproductive exercise, to that outrage on nature which is committed when two animals of different species, as the horse and the ass, are suffered to procreate. If, then, their offspring be paired, the secret antagonism of their better qualities, though insufficient, as in the instance of a mule, to forbid conception, is excited to activity, and, like the bed of a healthful spring, when thrown into agitation, corrupts the entire strcam. To justify the breeder's favourite maxim, these animals, since they betray outward evidence of a closer relationship to the sire than to the dam, should perpetuate their likeness through succeeding generations. But as well might we expect, by associating in marriage two persons of cultivated moral character, to witness a freedom from $\sin$ in their issue. The inveterate propensities of nature, whether moral or physical, are not thus easily disposed of; and I know not an adage that has prejudiced the interests of breeding, when used, as it most commonly is, in a wide and unconditional sense, so much as the trite saying that "like will beget like." 
Unfortunate as it may sometimes appear, that the constitutional peculiarities of an animal associated, by accident or necessity, with one whose distinguishing characteristics we may wish to superabound, cannot be conveniently annulled, it deserves to be considered that the same law which binds it to a perpetuation of its individual kind, we recognize as the pride of our hope in those of a happier mould, -and that it is but a literal application of the command originally instituted by Him who created all things, that the " earth should bring forth the living creature after his lkind, cattle and creeping thing, and beast of the earth after his kind."**

* For wise and beneficent purposes, the laws whieh preserve the various ranks of animals from generic intermixture, were originally constituted absolute in their operation. Had they been otherwise, we should have lost very early, in the history of the world, all trace of distinct and specifie breeds; and the falbled stories of Centaurs, Scyllas, and Chimeras, would have been subuitted to posterity as so many faithful portraitıres from real life. No misapprehension, however, prevails upon the subject, amongst those who either consult the aecredited testimuny of past ages, or estimate aright the evidenee afforded by their own senses. For whether roaming at large, unrestrained by the authority of man, or subjugated to his will, all living nature declares, that whatever Grod has created for onr inse, and His Providenee secured from the perils of the flool, shall enjoy the fineulty of maintaining (subject only to the modifieations which belong to dirersities of climate), through endless generations. their pristine form and eharacter. Hence all attempts to cnltivate hybrid animals, combining the properties of two distinct species, as mules do, for eximple, those of the horse and ass, are directly at variance will the intentions of nature, and can extend no further than the generation which imme- 


\section{Now suppose one of these animals, descended from the Scottish and Durham breeds, say the}

diately procecds from such unnatural alliance. Under no circumstances of which I have any knowledgc, has it been found that mules are capable of perpetuating the individual qualities thus imposed upon them, by sexual intercourse amongst themselves. And so renarkable is the difference of constitution observable anon;st the several kinds of animals, that the blood of the ox camnot be injected into the circulating system of the sheep, in any considerablc quantity, without incurring its destruction, though botl shall sharc in some degree the same common properties, and be subjected to similar treatment. They are both, fur instance, seen equally to delight in the same vegetable product; both chew the cud, and are unanimously allowed, by Jews and Christians, to furnish an appropriate food for man; and yet so distinct and unlike are they in the secret constitution of their nature, that the blood which, in each casc, is elaborated from one common food, by une common process, and made subscrvient to one grand ultimate design, camnot be transfused from one to the other, without endangering the life of its recipient. On the contrary, an intermixture of the blood of two oxen, two sheep, or of any other pair belonging to the same species, may be practised with impunity-a circumstance that tends still furthcr to prove that, to each of the ranks that comprise the vast catenation of living animals, belongs a peculiar and inherent principle unknown to the rest, and which neither depravity of instinct, nor human interfercnce can, in inywise, disturb. The fact is recognized by Lucretius, lib. i. 278, and again in the following passinge :

Lanigeræ pecurles, et equorum duellica proles,

Buceriseque greges, eodem sub tegmine coli,

Ex unoque sitim sedantes flumine aquai,

Dissimili vivunt specie, retinente parentem

Naturau ; ct ınores generatim quæque innitantur.

De Rer. Nat. lib. ii. 660.

'The stccl, the steer, the fleecy flock that range

Beneath the same pure sky, from the same fount

'Their thirst that quench, and o'er the flowery lawn

Crop the same herbigge, differ still, through time,

In form generic; each parental staunp

Retaining close, from sirc to sirc propelled. Gioon. 
heifer, be put to a short-horn bull (if to her sire the better), the contending disposition of the northern variety, to gain ascendency in the product, will be negatived by a preponderating influence of the opposite party; and, after a few generations, it will be thrown into complete abeyance. Henceforth is there no longer a prevalence of conflicting interests; one blood having been mainly adhered to, we discover an identity of form, feature, and habit in the family, whose members consequently assimilate as readily and harmoniously as do globules of quicksilver when brought into contact. This fact was turned greatly to the advantage of the original improvers of both the long and short horns, who were, doubtlessly, men of very accurate observation, and of strong reasoning powers. It was enough, probably, for them to learn that a similarity of feature and complexion in our own species, involves pretty much a similarity of disposition and temperament, to conceive the further idea that, by breeding from animals thus allied in constitution, they should be best enabled to preserve such constitution unimpaired,--and in no way could the alliance be so well secured as by in-breeding. So well did the scheme answer, that its propriety as a rule in practice became established: and no less success- 
fully, is there good reason to believe, the practice to have been conducted in the liuman subject, as well amongst the antediluvians as subsequently. But though in a fleshly sense it might succeed, it is equally clear that it must have unfitted man for the more exalted duties assigned to him by his Maker, and that, for wise and beneficent purposes, therefore, it was proscribed in the Mosaic dispensation. Still do we sometimes witness intermarriages, in contempt of the divine law, amongst those who are near akin ; and not unfrequently do we observe the contractors of such affinity doomed to sustain the penalty attached to mental or bodily infirmity in their immediate descendants. The subject $I$ heard first introduced by the late Dr. John Armstrong, who, when alluding to the physical defects of humanity, contended that they were more commonly induced by intermarriage on the part of those of kindred blood than by any other cause. I have since most carefully marked the issue of every alliance of this character that has fallen to my notice; and though I have often observed immunity from congenital ailments, it has been my lot to discover many instances of less fortunate result. To enumerate them would be to encumber the reader with a bare multiplication of 
facts; and as the names of the parties implicated could not with propriety be included, I shall confine myself to one case by way of illustration. Many years ago, I attended in labour a married woman of this town, who, on recovery, asked if I could suggest a remedy for a complication of ills occurring to two sons of the respective ages of seven, and nine, years. They were possessed of common intelligence; but the senses, as they are termed, were constitutionally blunted. Their vision was imperfect, and the margin of their eyelids habitually sore. They were deaf, and consequently unable to speak: taking them all in all, they were the most pitiful anomalies I had seen. It occurred to me that they might, possibly, be the offspring of cousins; and, on asking whether the husband and wife were related, except by marriage, they looked intently at each other for an instant, when the former exclaimed, "Oh! he means your first husband." They were the produce of a matrimonial conjunction with a male relative.

It will be remarked by all who have attended to this occasional infraction of Nature's laws, that its explanation is involved in very considerable obscurity. The case is somewhat analogous to that of the descendants of the Scottish cow and Durham bull, 
when allowed to procreate, except that there is not usually so much consentaneousness of feeling and action. There we have an issue from remote varieties,-but reared alike, and enjoying precisely the same advantages in respect of locality: the struggle for supremacy in the next generation would therefore seem to be equal; but as it is always easier, in the natural constitution of things, to negative a good purpose than to accomplish one, when even unassailed by opposition, the victory is most commonly gained by the less meritorious of the two rival powers. In the instance of cousins, it is most probable that they do not equally partake of the blood from which they have been each derived. Their parents on that side, unless they shall have been twins, may have differed in character-consequently there is no uniformity of action in the secret springs of reproduction: the interests are too many, and too variously blended to admit of it; and, as an ill-directed agency in physics is usually attended with disruption somewhere, so we have in their progeny deterioration to a greater or less extent. A fixedness of character on both sides, whether in favour of the common blood from which they shall have proceeded, or otherwise, least of all endangers their union. Precedence is then more readily 
maintained, or yielded to the opposite party, and less risk of violence incurred to the issue.*

Perhaps the most familiar illustration of female ascendency, in a copulative sense, is that which, in the human subject, a lymphatic temperament affords. People of this class are known by a general paleness and softness of skin, by a rotundity of form and feature, by their disposition to obesity, and by the colour of their hair, which is mostly flaxen, red, or auburn. They commonly possess little sensibility, having no care to sympathize with others in affliction, or to participate with them in pleasure. Selfishness is their prominent characteristic; and however hearty may seem their professions of friendship, the wary receive them with caution. They are easy of access; but the

* He who regards the proceedings of our legislative assemblies, will hardly fail to be reminded here, of an act passed a few years since (or rather a restoration of one, grown obsolete), prohibitory of nuarriage on the part of a man with a sister of his deceased wife. Such interdiction is professedly based on that portion of the old canonical law, which declares "Thou shalt not take a wife to her sister, to vex her, to uneover her nakedness, beside the other in her life time." -Lev. xviii.18. But what authority this passage affords for so 111 righteous an interference with the liberty of the subject as that complained of, I have never been able to divine. 'The mutual incentivesto marriage, where death has removed the only legitimate obstacle to a union, lave their origin, most commonly, in the best feelings of our nature. The rite is perfectly agreeable to the orlinances of God himself; and that enaetment whiel forbids it is framed in injustice-is a blot upon our statute book-and alike disereditable to all who were coneerned in its adoption. 
female portion reciprocating but faintly the attentions bestowed upon them by our own sex, it rarely happens that they obtain in marriage a truly independent-minded man. A wife so constituted seldom neglects to consult her own ease and indulgence; and the apathy she betrays in her general dealings with society, is either exemplified in coition, or she becomes a party to the contract for her own express gratification. The husband, on the contrary, is generally one of nervous excitability, fond of dispensing favour's to the other sex, and who, impressed with an idea that there is something more to be won by attention than he has yet merited, presses his suit with the tenderness of one actually on preferment. He considers it a matter of proud distinction to be suffered to caress her; and with the enthusiasm, therefore, of a devotee, does he engage in the pleasure of venery. In accordance with the doctrine I maintain, the physical character of the offspring, in such case, is determined by the mother, whilst the nervous attributes, involving temper, disposition, mental capacity, \&c., are inherited from the father, in proportion to the extent to which they shall have been lavished on his wife. We then witness the curious anomaly of a lymphatic subject, imbued with the ardour of a highly nervous principle, 
many instances of which, occurring to persons distinguished for intellectual endowments and licentiousness, might here be adduced.

So discordant an admixture of elements would, however, seem to be at variance with the intentions of Nature, whose efforts we shall presently see directed to a restoration of the balance thus lost in her operations,--for it rarely occurs that persons of this class are faithfully represented in their progeny. The animus of the male parent prevails over the medium through which it is distributed; and the next generation, unless overruled by a contending power, discovers a more slender forn, with the spirit of the grandfather. And thus do we once more arrive at an exposition of the secret of "breeding back," as it is termed. Spirit will prevail over matter ; and it is because the produce of the Scottish cow and Durham bull, though exhibiting the frame of the latter, possess the nervous principle of the former, that they develope the characteristics of their dam if allowed to propagate. The splendid calf begotten of Will Honeycomb, and resembling him so nearly in general structure, presented some local features, as the eye and feet, precisely corresponding to those of her dam; and so nearly allied to her in disposition and habit was she, that a little 
tremulous motion of the muscles of the thigh, on being relaxed, whenever the weight of the body, whilst standing, was thrown off one hind extremity upon another, was observed with equal exactness in them both.

It has been attempted by pathologists to reconcile scrofula with certain habits of body, which they have laboured to describe by reference to feature, hair, complexion, $\delta c$. ; and it is amusing to see that by such time as the most accurate of them have concluded the catalogue, they have embraced every temperament that words can well express. This they have felt compelled to do, in as much as the disease has been detected in those persons whose contour would, a priori, have seemed to claim for them an exemption. A man, for example, of huge chest, and betraying other indications of hardiness, has died of true pulmonary consumption-a disease essentially scrofulous in its nature, and which has most likely been thus incurred: his father has been a man of fine structure and constitution,- his mother of delicately interesting, though of scrofulous character-attached to her husband in the best sense that distinguishes a woman, and yielding, therefore, in her admiration of his person, the plastic oflice unto lim, at the same time that she has infused, 
by virtue of such exercise, her own radical disposition, with all its concomitant advantages and ills, into the offspring.

Independently of the direct authority which observation affords for the establishment of this doctrine, collateral evidence is not wanting to justify its adoption. We know that mental impressions received by a female, even subsequently to conception, from remarkable objects occurring unexpectedly to the sight or touch, inflict, not unfrequently, corresponding and indelible evi. dence of such impressions on the foetus, whilst at the same time we negatively prove that, in the mother's keeping, its native character is preserved uninjured. A friend of mine had, some time ago, a sow of highly nervous temperament, on whose back, as she one day lay asleep, when somewhat advanced in-pig, he suddenly placed a child. She started up in great fright; and, in the next litter, was one pig denuded of hair across its back, and partly down its sides, though otherwise well covered, as were all the rest of the family. Jacob's device for obtaining cattle "ringstreaked, speckled, and spotted," is known to every reader of sacred history; and a fact recorded by Mr. Boswell, in an Essay on the Breeding of Live Stock, and quoted by the editor of the popular treatise on 
cattle, as published under the superintendence of the Society for the Diffusion of Useful Knowledge, so well illustrates the question before me, that I cannot forbear to transcribe it. $\mathbf{A}$ gentleman in Angus had a cow in "season, while pasturing on a field which was bounded by that of one of his neighbours, out of which an ox jumped, and went with the cow, until she was brought home to the bull. The ox was white, with black spots, and horned." The owner of the cow "had not a horned beast in his possession, nor one with any white on it; nevertheless, the produce of the following spring was a black and white calf, with horns." It is obvious that she had become enamoured of the ox which had accompanied her awhile, and though ultimately impregnated by a black bull, she retained so vivid a recollection of her former associate, as to involve her issue in a resemblance of him. But that very operation of the sentient principle which brought about this result would pervade the tiny embryo so thoroughly, as to communicate to it the intestine characteristics of its dam; and the bull through whose agency conception was effected, would have virtually no more part nor lot in the scheme than would be discoverable in some unimportant local peculiarity. On the same authority it is stated that, upon a farn where pure 
black doddies were bred, but along with which an Ayrshire cow (red and white) was kept for some time, there appeared three red and white calves in one seasoll, and two in the following, when the proprietor, to break the charm which had been unfortunately introduced, disposed of the Ayrshire beast, and adhered inviolably afterwards to black animals, down even to pigs and fowls.

Referring again to sexual commerce on the part of a lymphatic female and a man of nervous excitability, I would just observe that, should reproductive intercourse between the parties be illtimed, as when the husband execntes his function without his accustomed zest, the produce is found to inherit a proportionable degree of inactivity; and, having commonly a huge frame to command, with so small an amount of nervous power, it rarely happens that such individual attains to more distinction in society than that which applies to mere animal existence.

A narrative I would now subjoin, as related to me a short time since by one of the principals in the drama, on whom I was then in attendance, in which two persons of the respective habits I have been treating were concerned. It well exemplifies the general truths 1 have been attempting to enforce, inasmuch as there is scarcely a link 
broken in the chain of evidence by which the case is supported. A gentleman, combining with much intelligence a considerable share of sensibility, was accustomed to visit an establishment in which resided a maid servant of prepossessing exterior, for whom he conceived a strong attachment. Once only did he gain an opportunity of conferring with her in private; and then his solicitations were met by so decided a remonstrance, that it seemed doubtful whether the influence of fascination could extend to her. At length she failed to preserve due self-possession, and whilst "whispering she would ne'er consent-consented," at the same instant bewailing her irresolution in a profusion of tears. However it may suit the interests of poetry, it is wholly irreconcilable with philosophy to suppose that a concession, thus procured, is to be received in evidence of love for the individual to whom it is rendered. But if testimony more conclusive than that which induction supplies be required in this case, it is abundantly discoverable in the subsequent history of the parties. The girl proved to be with child; and though the gentleman to whom the charge of paternity applied, entertained a doubt, for some time, concerning the truth of the imputation, yet did he place her, at his own cost, under the gurr- 
dianship of a creditable family, with whom she has already remained a year beyond the period of her delivery. Nevertheless, I am assured, not only by her patron, whose unsupported assertion I should cantiously admit, but by the people in whose house the girl resides, that, with a view to guard against the possibility of danger, she has, throughout her stay with them, refused to hold any communication with him, except in the presence of a third person. Now let it be borne in mind that this girl's mother is of a bilious habit, and subject, together with two sisters yet living, to biliary concretions (gall-stones). The girl herself presents external indications of a lymphatic temperament-an exact similitude of her father; but so strongly does she partake of the constitutional bias of her mother, that on several occasions I have known her jaundiced from the mechanical interruption to the passage of bile, incurred by the lodgment of gall-stones. And mark how this innate principle of the mother prevailed in conception! The girl had no fondness for her paramour,--selfishness, for the most part, induced her, after all, to yield to his importunities: whereas he loved her most tenderly, and conceded the right which she claimed to model the fotus, by reason of her abstract passion. The child (a 
female) was consequently born with eyes like those of its mother, but conveying, in every other lineament, a miniature representation of its grandmother. No feature identified it with the putative father, save that of its nails which dissipated at once all doubts that had been previously indulged respecting its descent.

Conformably to the doctrine I hold, this child should assume the constitutional habits of its father,-and that in some degree it does so, is already demonstrable; but his contributive services, it must be remembered, like those of the bull to which the Angus cow stood, after having been waited upon by a black and white ox, were, in a great measure, negatived by the internal conflict to which the girl became a prey at the instant of conception-and, as the sequel proves, to so fearful an extent did the law of sympathy involve the rudiments of the fotus in the grief incurred at that momentous period, that these two persons, both of whom are highly regarded in their respective spheres, for amiableness of disposition, stand as the authors of one of the most miserable wretches that ever took on the form of humanity. Though in the enjoyment of rude health, it cries almost unceasingly; and au umbilical hernia, consequent thereon, has already, in defiance of every 
effort of art, attained to such magnitude, that I shall not wonder if, in a few years hence, as in the instance of the late Horne Took, it carry the chief bulk of the chylopoietic viscera without the abdominal cavity.

Were it possible to note the circumstances under which impregnation occurs in the human subject, much of the inconsistency, made chargeable on nature, would admit of satisfactory explanation. Passions essentially animal are, of necessity, cultivated in a mutual embrace of the sexes; and they are so variously developed in different individuals, and in the same individual at different seasons, that uniformity of result cannot possibly be obtained in successive acts of reproduction. Hence, the moral and physical variableness observable in families proceeding from a like source. Amongst the unreflecting it often creates surprise, that children of seemingly religious parents should be with difficulty reclaimable from the follies and extravagance of youth. To say nothing of the frequent assumption of Christianity, as a matter of worldly policy, and the consequent irreconcilableness in the profession and practice of such people, it is to be kept in view that religion, in its true sense, is an acquired grace, and that, however admirably it may be 
suited to the regulation of our conduct in reference to God and to our neighbour, there are seasons when the best portion of mankind lose sight of its obligations,--and at none more palpably than in the matrimonial intercourse of the sexes. Devotion, whether in an arbitrary or strictly righteous signification, is incompatible with sensual indulgences. The former is verified whenever love, in its purest sense, disposes a man to address a virtuous woman. Deference to her expressed or implied opinion, and watchfulness over her for good, take the place of fleshly considerations : it is only when equality and identity of interests are established on marriage, that he feels her to be accessible to him in a grosser capacity. The latter is demonstrable in the lives of those who, whether attached to monastic institutions, or otherwise, are distinguished by a oneness of purpose in their worship of the Everlasting Father : they preserve a course of rigid celibacy, that no interruption may occur to their intimate communion with Grod. All spiritual association, therefore, in its noblest construction, is suspended during the period of sexual correspondence, and the natural character indulged; and when to the fact that prudent men seek such gratification only when impelled by the salutary 
dictates of nature, and consequently incur a liability to beget a robust offspring, is added the persecution too often employed in the persons of their children, whilst young, to enforce an observance of religious ordinances, the cause of insubordination amongst them is pretty clearly made out. To dwell on the probability that, in many cases, the parties are " unequally yoked," and that a moral taint may be thus inflicted on the progeny, or to entertain the evils arising from unfortunate communications at school and elsewhere, would be to extend my observations beyond the limits assigned to them in this place. I would, lowever, remark that whilst faculties of an objectionable character are engendered under circumstances favourable to the moral interests of society, and transmitted from parents to children, how justly is the crime of illicit intercourse to be deprecated, since it calls into exercise some of the worst passions of which we are susceptible. The nervous vigour that prompts to its indulgence, and confers, not unfrequently, upon bastards a prowess for which, in every age of the world, they have been remarkable, entails upon them also a recklessness of disposition inimical to usefulness, in the solemn and more important duties of civil life. So generally has the fact been recognized, 
that it was anticipated, even in the alliance of Abraham with Agar; and perhaps no better evidence can be had of the divine origin of the Pentateuch, or of the truth of the principles which I am desirous to convey, than is furnished in the history of Ishmael and his descendants. Whilst yet a lad, he was banished from the land of his father for filial disobedience; and, when having wandered, with his mother, in to the wilderness of Berr-Sheba, the prediction that he should be "a wild man," and that "his hand should be against every man, and every man's hand against him," was literally fulfilled in him and his posterity. For, though "many potentates amongst the Abyssinians, Persians, Egyptians, and 'Turks, have endeavoured to subjugate the wandering or wild Arabs, whose possessions may be said to extend from Aleppo to the Arabian sea, and from Egypt to the Persian gulf,- a tract of land not less than 1800 miles in length by 900 in breadth, yet have they been ultimately unsuccessful." Having cultivated close affinities, like the other descendants of Abraham in the line of Isaac, they are the only inhabitants of the earth, besides the Jews, that have existed as a distinct people from the beginning; and the original habits of their founder having acquired an inveteracy, by reason 
of such practice, it is easy to conceive that the various tribes of which they consist, will ever be found difficult of foreign subjection, and of moral culture.* A consciousness of the danger of confiding offices of trust to the keeping of an illegitiinate product, led the ancient Israelites to refuse them all participation in civil privileges, even down to the tenth generation; and it is not improbable that an intuitive knowledge of the wortllessness

* The specific institutions of Nature for maintaining in perpetuity the eharacteristics of such animals as would otherwise suffer from domestic interferenee, call hardly be eontemplated without referenee to the wisdom and goodness of Him, at whose instanee they were estiblishel. 'The requisite irritability of eats, for example, is guaranteed in the uproar they preserve during the act of eopulation; and theseerning atrright in which the tame female rabbit invariably runs, pursued by the buck, before yielding to his importunity, secures to lier young a like property, in no less degree than is slared by those whieh are born of wild parents, - as proved in their jerking, involuntary efforts to escape, if disturbed, when cven a day or two old, and by other manifestations of impatience, till lulled into quietude by perserering familiarity. 'The Arabs, who are a shrewd race, I suspect to hitve been long atware of the influence, on the offspring, of impressions received by parents, about the period of reproductive intercourse, and to lave derived no little advantage from such knowledge, in the breeding of their celebrated horses. I know not whether the experiment has been adopted in our racing establishments, but it is worthy of trial, when a mare is ascertiined to be in season, to cauter liel brislily, say half, or three quarters, of a mile, to the place where she knows the stallion to be in readiness to eover her. A foal so obtained, I am disposed to think, would, caleris puribus, possess a fleetness and emulation far execeding sueh attributes in onc-engendered "between sleep and wake." 'The principle was urged by Columellit, in its application to the stallion (Lib. 6, cap. xxxrii.); but, for reasons which cannot here be convenicntly discussed, it most properly applies to the mare. 
of this class provokes the contempt with which they are almost invariably treated. Every man of reflection, however, must learn that the issue of an unlawful connexion presents a peculiar claim to the exercise of sympathy; and whilst the difficulty experienced in adapting them to the more dignified purposes of life shall continue to be a subject of complaint, it should incite both sexes to a maintenance of self-government, at variance with the cause of so frequent and unhappy a result.

Corresponding to the lymphatic temperament in the human subject, may be noticed, now and then, in almost every variety of cattle, a figure combining neatness with a singular disposition to fatten. 'The particular indications of such disposition consist in a bright placid eye, a somewhat rotund, but smaller, chest than belongs to those which are equally remarkable for muscularity,--a thin, soft, unctuous skin, and a close covering of fine, glossy, silk-like, hair. If pastured on moderately rich land, that yields not a very succulent herbage, an animal of this kind quickly grows fat, but seldom answers the purposes of the dairy. Of a truth "self-preservation," with her, "is the first law in nature," and nothing short of treatment that shall impose a general laxity of fibre, can make her 
available to any other interest than that of the grazier. In keeping with such constitutional selfishness, a beast of this class not uncommonly fails to breed, or, in the event of conception, she furnishes a product more nearly approaching to her own likeness than to that of the bull to which she has been affianced. But as no instruction can be so well conveyed as in its immediate application to practice, I will illustrate this part of my subject with the history of an animal that was long in the possession of the late John Wright, of Lenton, Esq. When passing through his land about six year's ago, I was arrested by the singularly elegant appearance of a red cow; and, being desirous to know her origin, I sought an interview with the ground bailiff (Rouse), who told me that, when three years old, she was bought, along with another of like age, and of nearly equal quality, of .Miss Evans, of Beeston, for $30 l$. She had bred several calves, most of which were females-red, and inheriting her native properties in rich perfection. Two of these descendants, a three-year-old heifer, and a two-year-old, were shown to me. The former was exceedingly symmetrical and fat, and, according to the testimony of my informant, had been repeatedly, but fruitlessly, bulled. Tradition ascribed to the dam a distant connexion with Mr. 
Wilkinson's cattle; but as evidence to that effect appeared, by no means, to be satisfactory, I could only conclude the alliance to have been of very remote date. Mr. Wright having no predilection for good stock, she had been always put, in common with other cattle upon the farm, to a bull of mean birth; yet under such disadvantage had she bred the heifers to which allusion has been made. At this stage of the detail, I may as well remark that the oldest heifer, continuing to disappoint all hope of impregnation, was sold to a butcher on the 7 th March, 1837, when four years old, for $38 l$. Feeling interested in the character of one which, without any valuable adjunct, had thus distinguished herself as a parent, and being assured that the sole management of the farm was intrusted to Rouse, I offered him 30l. for this cow, when ten years old, in low condition, and worth, at most, but $18 l$. in a market. 'The man, however, knew his master to be rich, and was pleased to conduct affairs rather in compliance with the dictates of caprice than with a view to considerations of profit, and so declined my offer. I next submitted that he should introduce her and the younger heifer, not yet in calf, to Mr. Wilkinson's favourite bull, and, whether male or female, I would give for the produce of each, at birth, five 
guineas. To this he would not agree; but, thinking it might be well to speculate on my proposition, he put one to Will Honeycomb, and another to Frank, as he was called, and waited the result. The cow brought twins (male and female), one of which (the female) died at birth, or immediately after; the other I was offered on the terms originally proposed: I refused it, though it bore a close resemblance to its dam in colour, shape, and quality. It was eventually disposed of to one of his kindred in Leicestershire, in whose service it has been employed nearly three years. I am told that, as a bull, he has always handled well, but, like his dam, has never made much flesh. The daughter produced a bull calf, radically defective, but the farmer thought otherwise: "it was well timbered," he said, and "spawny ;"* and being desirous to make these properties available to the interest of his friends, he sold it to one of Mr. Wright's tenants, a highly respectable farmer in the vale of

* He who has been accustomed to hear the word "spawny" used in reference to young animals, without troubling himself about the propriety of its application, knows well the sense intended to be conveyed. A "spawny" animal is one whose aggregate length and leight far exceed the proportions of its trunk, and is commonly regarded by those who enjoy not the faculty of observation in an enviable degree, as "promising to grow into a gond one." Should it be "well-timbered" withal, and equally well fed, it may be expected to carry as much flesh as will enable it conveniently to sustain the office of locomotion. 
Belvoir, who kept it nearly two years, and then killed it in disgust. Once more $\mathbf{I}$ proposed to stipulate with Rouse for the produce of both mother and daughter, but, failing in my negotiation, I neglected to visit the farm. Intelligence, however, reached me that the cow had slunk her calf, and been sold in Nottingham market for $13 l$. The heifer, in due time, bred a cow calf, which was kept upon the estate. Again she calved, and soon after died-the carcase realizing $20 l$. to one of our Nottingham butchers.

In what manner those who contend for an absolute and unconditional control of the sire in the breeding of stock, will meet the difficulty involved in the consideration of this red cow and her offspring, I know not: to my mind the case admits of very easy solution. She entertained just as much physical love for the bulls to whose gratification she contributed, as does a handsome voluptuous woman for a man who, in the absence of personal attractions, commands neither wealth, rank, nor mental accomplishments. Governed by the influence of a generative passion, the cow would stand alike to the vigorous and emasculated; but whilst one might have possibly enkindled in her affections a generous recognition, the other 
would be received with comparative indifference.* Let him who doubts the justifiableness of such analogy, mark the identity of feeling in man and brutes, where moral refinement softens not the heart. Let him witness the seeming cordiality with which a member of each sex, from out the lowliest rank of civilization, will conduct a têtea-tête, till startled by a rival lover,-and when the first suitor shall have been soundly pommeled, view the fair subject of contention "pair off" with the hero in all the majesty of brutal pride;-and then turn to a party of domestic fowls, absorbed in an affray between the male partner of their joys, and a spirited intruder. A few minutes decide the fate of their old associate: he is beaten; and one short valedictory blessing terminates their acquaintance with him. The adage that "none but the brave deserve the fair" belongs not exclusively to any particular section of the animal

* An objection may be taken to this argument, since the surviving calf of twins, begotten of a first-rute bull, appears to have inherited his dam's general character. 'The fact of his having done so tenrls but to justify the portraiture I have drawn of animals of the lymphatic class. The cow's native habit triumphed over the charm of individual attractiveness on the part of the bull; and, without considering the gencral argument at all disturbel, I am bound to confess that the allnrement employed in this instance was insufficient to accomplish the purpose for which it was designed. 
kingdom: it is of universal adoption, though influencing its votaries in proportion to the extent in which sensuality shall prevail. Hence it is not uncommon for a female, as a sow for instance, whose fondness of the boar is proverbial, when in despair of being requited for her visit, to attempt what she would delight to see another member of his sex accomplish - an infliction of bodily chastisement. If the male conquer, as most frequently happens, a two-fold object is secured-the sow regards him with admiration, and the nervous excitement engendered in the struggle, prompts him to the service which he had hesitated to perform, and impregnation follows. It would be equally absurd to argue that a boar, under such circumstances, would beget a good litter, as to insist that the sire of Mr. Wright's heifers conferred upon them the properties for which they were esteemed. He felt, on being introduced to the cow, as would an ill-conditioned man, if invited to a fleshly covenant with a female to whom he had not thought of aspiring, - a languishing, deferential regard. Had he been less enamoured of her charms, the remote consequences of his employment might have been averted. But unluckily the cow interested him enough to inherit for her offspring a participation in his constitutional infirmity,-and this disposition 
predominating in the heifer, when, in due time, she was presented to the bull, gave promise of that which was realized in the next generation-a "spawny" and "well-timbered" calf.

Another, and by far the most prolific source of female ascendency in the propagation of our species, since it applies to individuals of every temperament and condition in society, is to be found in the pitiful motives by which too many are influenced in cultivating a matrimonial alliance. When in rural simplicity we lived, it was accounted a privilege by man to labour for the support of a virtuous woman : but modern refinement as it is called, has effected a singular change in the feelings and disposition of my countrymenso much so, that one might almost venture to offer a reward for the discovery of a young gentleman, whose sensibility is sufficiently blunted to admit of his smoking cigars, and drinking brandy and water, that does not think he is entitled to a maintenance at the hands of that lady on whom he shall condescend to bestow himself in marriage. And being free to speculate on this principle, attachments are feigned, affections won, promises broken, and hopes blighted, till at length the day of retribution comes, and when the perpetrator of such outrage thinks to participate largely in the 
enjoyment of comnubial sweets, he learns that the happiness of his fair elect has been compromised -and that

"Life hath no wore to bring

'To her but mockeries of the past alone."

Yet having sealed each other's destiny on terms irrevocably secure, all other considerations are usually suffered to merge in the one absorbing question-by what means a creditable relationship to the world is best to be maintained. The engagement, whatever it be, soon diverts the mind of him on whom its fulfilment principally devolves, from contemplations of a domestic and painful character. But neither time, nor changing circumstances, can dissever the association by which his wife is kept inthralled in the interest of another. Though " absent in the flesh," remembrance will, in wanton mood, restore the lost embrace; and instead of yielding to the requirements of her husband in a spirit of pure and unmingled regard for his person, she assumes an air of abstract voluptuousness; and, if she bear children, stamps upon them her own individual impress, leaving him to whom they are in some measure indebted for existence, to confer, by way of supplement, just so much of his own peculiar habits and liabili- 
ties as shall correspond to the amount of affection entertained for her at the instant of copulation.

Nor is this evil in a trifling degree aggravated, by the gregarious character necessarily imposed on the growing population of the country. Females inherit a greater abundance of that animal constituent (fat) whose chemical base is intimately allied to the smoke we disengage in the burning of coal than do men; and by the same law which enables pigs to thrust their heads into straw, and breathe the carbon thrown off from their orvn lungs, in the process of respiration, and get the fatter for it, are they enabled to bear a residence in a crowded city, with less personal suffering than is sustained by ourselves. This fact will partly account for the numerical preponderance of females over males in densely peopled districts. But a further explanation is to be arrived at by reference to the general habits of men in these localities, as affecting their private correspondence with the opposite sex. Contrary to the usages of rural society, the inhabitants of large towns are required, for the most part, to conduct their business in illventilated, unhealthy apartments, and at the same time to bring into exercise a considerable share of intellectual acuteness. A depressing effect, proportionable to the extent to which the consti- 
trution is thus taxed, necessarily follows; and to meet such exigency, recourse is had to stimulating fluids, and artificial treatment, of whatever kind, promises to recruit the declining strengtli. Hence a state of nervous excitement, to which the animal system holds no just relation, is being almost perpetually maintained, and which discovers itself, most of all, in impotent attempts to gratify a fleshly inclination. Where the primary cause of mischief alone prevails, as the conducting a mercantile or other active employment which shall involve incessant bustle and anxiety, and that too, under circumstances of atmospheric noisomeness, the consequences are felt, though in a less humiliating degree, in a reproductive effort. An irritability disproportioned to physical aptitude commonly incites such men to sexual negotiations which, if not inefficiently performed, require to be aided by all the artifices that a voluptuous imagination can suggest. And in resorting to the use of pitiful expedients, I need hardly remark that, of a verity, they resign all pretensions to manliness in the sight of those on whom their caresses are lavished. Women can only be charmed by men, so long as the latter preserve the dignity of their sex : when they cease to do that, as in the instance of the emasculated subjects in question, they are permitted to retain the privilege of copulation, as 
it were, by sufferance, and the female chiefly subscribes to the establishment of the fotal character. 'This alternative realizes a majority of females in the issue; and it becomes a matter of consideration with senators and divines, whether the returns of the late census, which develope a fearful increase of females over males, is not to be regarded as an indication of decline in the moral and physical constitution of Englishmen.

In those counties which include large manufacturing towns and cities, as Middlesex, Lancaster, Somerset, Gloucester, Surrey, Warwick, etc., where a corrupt atmosphere and dissipation ravage the male classes, a vast preponderance of females is discovered. On the other hand, the counties of Derby, Essex, Hereford, Salop, Westmorland, Wiltshire, etc., which embrace smaller towns, and whose male population are required to work too laboriously for bread to admit the practicability of excesses, the masculine character is better sustained, and we have, consequently, a bare majority of females: whilst Lincoln, Monmouth, Rutland, and Stafford, whose male population are more generally distinguished for hardiness, exhibit a balance in favour of that gender. I am aware that it may be contended that this showing only supports the position with which I started-that women bear a confined unlealthy 
atmosphere better than men-a fact which, when taken in comnection with their more temperate habits, would make it appear that a want of correspondence in numbers is simply referable to louger-livedness on their part. But whatever weight may be attaclied to this argument, I am convinced that where sensitiveness (which may be either hereditary or acquired, and in the latter sense it is pretty sure to be found as the concomitant of physical prostration) exceeds, whether in man or brutes, that of the female to which they are applied, a preponderance of female offspring is the result. My authority for adopting this opinion is strengthened, in no inconsiderable degree, by collateral evidence. The first-born of parents, in a coujugal state, is most commonly a girl, resembling, in its lineaments and general contour, the person of its mother, or some one to whom she is closely allied in blood. Now, it is well known to those who are conversant with human actions, and the feelings by which they are governed, that, as a rule, a man entertains a more cordial regard for the object of his choice, at the period of marriage, than she does for him. Having exercised his virile faculty already, he can anticipate the pleasure in reserve for him; but she, on wlom the modesty of her sex has imposed restraint, can 
form, as yet, no definite idea of the sensations experienced in coition. Unless she be one whom no man of cultivated taste would select, timidity will predominate over every other passion; and for some time after their intercourse shall have begun, the enjoyment will be confined almost exclusively to himself. When the customs of a married life shall have made her somewhat familiar with indulgence, she will fear to betray emotion, lest suspicion of native indelicacy should arise in the mind of her husband; and if, whilst studiously observing a selfish gratification (for I know not low otherwise to designate it), and before the glow of conjugal tenderness shall have declined in the husband, impregnation supervene, the child will, most likely, be feminine, and though partaking of the external characteristics I have mentioned, it will be strongly imbued with the spirit and hereditary liabilities of its father. The first ebullition of passionate love over, each party takes on the manner I have endeavoured to reconcile with the several forms of individual feeling and habit.

It is sometimes remarked, though I know not exactly on what data, that a liealthy pair who should choose the city of London as a place of permanent abode, and there engage in the work 
of procreation, with an understanding that their children should comply with similar terms, would be unrepresented in blood, after two or three generations. I can readily believe that this would commonly happen; for admitting the theory I hold to be correct, that, in such locality, the mother do, for the most part, command the physical character, with the certainty of a vitiating influence from the father-this influence, consisting, mainly, of his nervous faculty, would be inadequate to the preservation of its associate clay, and premature death would occur to the issue : or, in the event of longer life, hereditary decline would extinguish the family after the lapse of a few more years.

Oft as precedence is taken of the husband, under circumstances to which I have just referred, it is no less true that to him is frequently conceded the exercise of his just prerogative. We then witness in the offspring what may be paralleled on most badly conducted farms, a delicacy of frame that threatens disqualification for the purpose to which it is to be applied. Nor is it material whether the father present, in his person, a spare form, as induced by anxiety and other debilitating causes,-or the bloatedness of intemperance,-if his irritability incite him to outrage physical capa- 
city, the seminal fluid will be emitted before it shall have received animal maturity, and the product will inherit a worthlessness of figure, with such modification of the sentient principle as the female parent shall have been able to impart. And thus is it that the conceit of little, ill-contrived, waspish, subjects is to be explained. Here I may prepare to encounter some demur from all rigid sticklers for reliance on the old doctrine that "like will beget like;" but, with a promise that the argument shall be resumed hereafter, I conjure them to look at the progeny of the lustiest innkeepers they can find, and then say with how much truth their favourite dogma unconditionally applies. I should have little difficulty in furnishing a volume of practical refutation.

For corroborative evidence of the fact that nervous irritability must not predominate, in excess, over the animal system, for whose government it is intended, or a lean spare issue will be the consequence, I refer to the ordinary class of males in the possession of British farmers. In them a contracted chest forbids the requisite purification of the blood, whilst circulating through the lungs; and it is returned again to other structures, in combination with more or less of that deadening property which it is the object of Nature to dis- 
engage in the act of breathing. This being the case, a train of phenomena discoverable in all animals during sleep, when respiration is being slowly conducted, almost uniformly prevails; $i . e$. the secretions participate in the unhealthy character of the blood, from which they are eliminated, and are with so much difficulty sustained, that the standard of health may be said never to be arrived at. Hence, if undisturbed by exciting causes, such animals appear languid and drooping ; but if associated with females of their own species, they are constantly being prompted to attempt what a defective constitution can ill afford to perform. One of the best schools for verifying this remark is a park or other inclosure, appropriated to the reception of store cattle, amongst which a few bulls are turned. Lord Rancliffe's seat at Bunny affords a convenient illustration. There have I often seen during the months of summer, two flat-sided, worthless, bulls, each with the penis protruding, for hours together, in pursuit of females, till the mechanical irritation occasioned by the presence of flies, and fruitless efforts to copulate, has reduced them to a condition alike disgusting and pitiful to contemplate. To say nothing of the waste of body incurred through want of full regular meals, rest, and deliberate 
rumination, the vital principle is so fast consumed, in such an instance, by indulgence in physical love, that the general system, though greatly attenuated, and requiring, therefore, a correspondingly diminished succour, fails to enjoy its rightful superintendence, and the seminal fluid, at best, is endowed with a bare reproductive property. ${ }^{*}$ My personal acquaintance with many who have grazed sturks in Bunny park, has given me an opportunity of noticing the shape and quality of stock, begot-

* To those whio are unaccustomed to refleet on the causes affecting animal existenee, this explanation may be rendered more intelligible by remarking that whatever engrosses the mind, in any of the endless modes in which it is exercised, to a vast extent, deprives the body, in i eorresponding ratio, of its energies. Hence are they who liabitually "look on a woman to lust after her," though evading the sin of practieil adultery, exposed, in eommon with poets, philosophers, and seholars, to premature infirmity and decay. Hysterieal, and even ret more formidable, nervous affeetions, frequently owe their rise to libidinous associations of thought, in persons of both sexes, where no actual vice stains the charaeter. And of course the more suddenly and violently these operations of the mind are called up, the more disistrous are the results: thus excessive emotion, whether arising from joy, grief, or aread, induees immediate weakness, and has been known, in people of very excitable disposition, instantaneously to absorb, as does electricity (lightning), so mueh nervous power, as to leave the heart unprovided with a stimulus to contraction-in popular language, to drive the life ont. When nervous efforts, to whieh an individual is unadapted, are indulged consentaneously with physieal exercise, as in coition, it occasionally happens that paralysis, or apoplexy, immediately superrenes on emission. I have known several sucli cases soon af ter the parties have retired to rest. Death, under like circumstances, las sometimes occurred to the buck rabbit, the stig, and other animals of highly salacious character. Mr. Wilkinson, of Lenton, related to me in instanee in a stallion a short time since. 
ten of his Lordship's bulls: worse it would be difficult to find within the range of pretended cultivation.

The parks of our nobility not unfrequently contribute another example of the ill effects of extreme nervous irritability, in the degeneracy of hares. When allowed to multiply within prescribed grounds till each other's privileges are invaded, the bucks are kept in such a constant state of fretfulness as to tell very prejudicially on their young. It is not, therefore, when hares fail to reach eight or nine pounds in weight, that the land on which they are bred is insufficient to rear them, but that the irritability of the male class is out of proportion to their animal developement.

A still more satisfactory illustration is to be found amongst the poultry of our farm yards. When, in the early part of spring, the male fowl blooms with freshness and beauty-dropping his wing, and prating to his little auditory all the day long, - inviting them, ever and anon, to some newly discovered feast - then asserting with "shrill clarion" the indisputableness of his dominion-the nervous and animal powers are blended in harmonious conjunction. Chickens obtained from him under such advantages, burst from their shells in happy chirping mood; and though in the 
variable month of April this occur, they proceed to maturity with unabating vigour. In May his flesh is gone: still does he tread the hens, but with what less effect the following chicks attest. Some, probably, will not survive the process of incubation; and those which do will be feeble and unthrifty-uttering oft a plaintive tone, and stepping with awkward gait, till released, by accident, from trouble, or, in a few months after, by the design of their owner. Common prejudice ascribes this defect in later hatches, to an abridgment of their summer; but having bred an immense number of fowls, and marked throughout successive broods, a correspondence of the chicks, at birth, with the gradual decline of the male bird, I am able to speak with confidence on the subject.

Perhaps one of the finest illustrations of the theory I am advocating, is that which the English race horse affords. His nervous vigour so far exceeds the amount required to keep in healthful exercise the living body, that without the least detriment to the natural functions, he can afford to expend a vast superfluity in running. This would, a priori, warrant an assumption that he would beget a proportionably vigorous offspring. And so he does, in a nervous sense : but his figure 
by no means answers to that which we require in an animal intended for human sustenance. Even muscularity, which constitutes his proudest feature, is, in a majority of instances, mainly acquired by the training to which he is subjected. The chest is not large enough to admit of his being generally and plentifully covered with flesh. To correct this fault it is necessary to moderate his irritability, which would be best done by imposing a little higher condition, together with corresponding, but not distressing labour, on such as are applied to the purposes of breeding. Instead of the restless colt which now, too often, appears with a loin like that of a donkey, we should have a product after the form of Mr. Rounthwaite's Governess,* Mr. Batson's Plenipotentiary, and

* I harc often desired to learn what character Mr. Rounthwaitc's Governess sustaincd, in the capacity of brood mare. I am no sports man, as every one will believe when I say that I never caught a fish, shot a bird or other animal, or bet a shilling on a coming event. But I well remcmber witnessing what I considered to be an extraordinary performance on the part of this mare at the Nottingham meeting of 1826. She first ran for the Macaroni stakes, two miles and a half, carrying 11 st. $13 \mathrm{lb}$., against Mr. Charlton's brown colt Bestwood, and won easily. In half an lour afterwards, she contended against Mr. Platel's ch. f. Conviction, and Mr. Trench's b. g., by Ambo, for the King's plate, then a cruel race of four inilcs-heats, carrying 11 st. $7 \mathrm{lb}$., and although the weather was excessivcly hot (Aug. 3), she seemed, by no means, distressed, after winning the first and second heats. Hcr custom, it would appcar, was to take the lcad and keep it; for she ncver suffered her compctitors to approach her-and I could not discover that licr rider inflicted punishment in any form. 
Mr. Houldsworth's Vanish; and all that would be demanded of the trainer, to preserve their adaptation to the course, would be to enforce exercise in proportion to the activity with which the purposes of digestion should be answered.

Similar treatment would correct the form, and, by lessening irritability, render more tractable our Alderney cattle. Their fretfulness was originally induced by the impoverished condition in which they are kept upon the islands, whence they are imported, and it has long since become inveterate: so that when promoted to the generous fare of our best rural establishments, they are found difficult of management. All who are intrusted with the care of Alderney bulls, concur in their report, that after the first six or eight months of the animal's life shall have passed away, an irritability supervenes, for which no remedy can be found. His Grace the Duke of Portland has long been in the habit of cultivating this variety; and when inspecting his herd, at Welbeck, a few years ago, I was assured by the

She proeeeded from Nottingham to York, where, in eight days after her former aehievements, she ran for the King's plate, four miles, heats-beating easily Mr. Haworth's gr. m. by Comus, out of Flora, and Lord Kelburne's eh. f. P'urity, by Octarian. She combined nervous and physical requisites, in greater perfection than any ofher mare I have seen. 
bailiff in attendance, that he lad never known a quiet bull. On looking at two, over a low door, which I was pleased to find a sufficient barrier to more intimate communication, my ears were stunned with the bellowing they set up. However desirable it may seem to bring them into subjection, a serious obstacle, I fear, applies to any attempt to improve their temper by augmenting the bulk of their carcase-since every step we should take in the attainment of that object, would be one lost to the interests of the dairy.

Having said thus much on the results of reproductive intercourse, where nervous irritability transcends physical aptitude, I will hasten to a consideration of the subject, as it occur's, where an opposite predominance obtains.

That a contrast is to be found, amongst members of our own species, no less remarkable than in the instance afforded by the blood-horse and one of coarser variety, will be admitted by all who observe the manners of a well-bred gentleman, as distinguished from those of unpretending simplicity. And without affecting to deny the influence of education, in exalting the character, it is contended that no effort of art could advance to equal distinction, individuals selected from each of the two circles. An absorption of the best 
faculties in manual labour, leaves those who are doomed to live by such exercise, in too prostrate a condition, to allow of their participating in the common gaieties of life, or the pleasure of venery, under circumstances however inviting, with that zest which is characteristic of extreme cultivation. The entire animal functions may be preserved in their native integrity, and furnish indications of health which they who "sit in high places" might envy; but after all we recognize, in this form of existence, an insusceptibility to impressions that would hardly seem to comport with beings who are destined, hereafter, to take on the intelligence of angels. One unvarying round of daily toil, alternating only with the whisperings of instinct, marks their career, and reduces them, on each returning eve, to the condition portrayed by Gray in his inimitable elegy :

The ploughman homeward plods his weury way.

Copulation, on the part of such men, is conducted with little more than regard to mechanical usageso that for want of the requisite incitement to commerce, the semen, though healthy in character, fails to communicate that powerfully vital impulse which is inherited in the event of a rapturous embrace. The germ takes on a reproductive 
action, and provided that the mother's condition be favourable to its developement, a bulky offspring is eventually produced; but all the processes of foetal growth betray an economy of purpose that can only be reconciled with deficiency of momentum in the first instance. Bone, for example, which is the meanest of all animal constituents, is largely bestowed, and involves its possessor, in the absence of due nervous activity, in that unseemliness of gait, for which people in the lower ranks of life are remarkably conspicuous.*

Such also may be said of the old-fashioned breed of cart-horses; but were they, or the men who drive them, promoted from the severer forms of labour, that hold the best faculties in bondage, to comparatively light, exhilirating, duties, their descendants would present, after the lapse of a few generations, both nervous and physical attributes but distantly resembling their own.

It cannot have escaped the notice of practical men that, though originating in a cause remote

* The force with which this rationale applies to a race of men, said, by Mr. O'Connell, to be the "finest peasantry in the world," will be seen on glancing, for a moment, at the moral and physical condition of the Irish labourer. Subdued in spirit by servitude, low diet, and priestly domination, he never, but when excited by whiskey, or its equivalent in some form, attains to that elasticity of limb which bespeaks a cupacity for pleasure : hence the rudeness of his structure, as exemplified particularly in respect of bone. 
from that of hard labour, bulls and other male animals, whose form and quality it is desirable to perpetuate, are occasionally to be met with, either wholly devoid of sexual appetency, or partaking of the faculty in so trifling a degree, as to be of little worth to their owners. The cause is most commonly referable to over-feeding of the parent stock. In them, as in all animals that enjoy not a great amount of nervous irritability, there is an obvious tendency to fatten: but rarely do they carry inuch flesh. Independently of their inefficiency as stock-getters, they, and their posterity, are particularly liable to disease ; ${ }^{*}$ for that modicum of vital principle, which scarcely allows

* It is here worthy of remark, how greatly an adhcrence to general principles will serve us, in the invesigatiou of science. The nervous lassitude of our rural population, embracing as well the industrious farmer as his servant, is a subject abounding with interest, alike to the physician and the physiologist: for having to contend with the vicissitudes of slimate, with the constant demand for concessions on the part of decaying manufactures, and with those direct emissaries of the devil, who deal out destruction by firc, such individuals arc pcculiarly liable to some distressing form of mental association, in which nervousness, according to the popular acceptation of the term, consists. Thus farmers are observed to be habitually croaking: it is either too hot or too cold, too wet or too dry, for their operations to be advantageously conducted; and were it not for the salutary influence of pure air and exercise, a vast majority of this useful class of men would be thoroughly hypochondriacal. And so are the dispensations of this life equalized: every condition, along with pleasurc, engcnders corroding pain; and that which I sometimes think would make me the liappicst man in the world, might worry me with its cndlcss cares. 
the expenditure required, to carry out the scheme of reproduction, soon fails to preserve its own system in health, under the assaults to which it is necessarily exposed. A red bull of this class, bred by $\mathrm{Mr}$. Whittaker, I believe, and sold at a high price to the Marquis of Exeter, subsequently fell into the hands of Mr. Walker, of Eastwood. He was always more intent on filling his belly than on answering to the invitation of cows: an hour would be sometimes spent in coaxing him to his work; and not unfrequently was he led away, unable to comply with the demand upon his services. His brisket, which was very depending, was alleged by the herdsman, in the simplicity of his heart, to incur so much difficulty in being carried over a cow's back, as to discourage him in the attempt. He never got a truly good calf, whilst in Mr. Walker's possession; and at length taking on some ailment that rendered him worthless in every capacity, he was sold, for a few pounds, to one of the numerous candidates for such a commodity, with which a town like Nottingham always abounds.

A friend of mine bought an in-calf heifer at Mr. Maynard's sale, which, in due time, gave birth to a bull calf, from whose services he expected to derive much profit. I was not so san- 
guine about the issue-for his dam, though of unexceptionable quality, betrayed a slight disposition to a defect, more frequently seen in pigs and tame rabbits, than in any other class of domestic animals, and which conveys to one's mind an impression, that a belt has encircled the chest, and impeded its growth, whilst all other parts of the body have been suffered to advance uninterruptedly.* When a few months old, the infirmity

* To explain the cause of this anomaly lias puzzled me exceedingly. 'The fact that rest is essential to fattening, and that this deformity is found only in those animals which are greatly disposed to fatten, would makc it appcar that their aneestors have, whilst earning a reputation for obesity, indulged much in a love of quieseenee-that the lungs not having, thereforc, been so fully inflated, as in the case of more irritable subjects, their investing parietes have eonformed only to the requirements exacted from them; at the same timc that nature has enforced her demand, that, however unequally distributed, the customary wcight of earease slould be attained to. In awhile the crror has become inveterate; and though exereisc may lave been inposed on their posterity, with a vicw to its correction, at the usual period of invasion, a depression in the spine has been pereeived, immediately behind the shoulders, which has daily appeared more palpable, till at last the body has seemed to be eompounded of fore and hind parts that would have well eorresponded, but for a thoraeie eonstriction that has spoiled the effect. Every pig I have known to be the subject of sueh malfurmation, has been derived from the stoek of some gentleman who has long been reputed for the excellence of his breed. From out many instances, I may namc that of four uncut, well-bred, male pigs, lately bought by Mr. Edge, of Strelley, for the purpose of being employed as boars, but which werc all proscribed on aceount of this fault.

I have thought it advisable to let thc preceding note stand; but since writing it, I have devoted mueh time to the management of a litter of pigs, for the first threc montlis of their lifc, with a view to 


\section{began to develope itself; and by such time as he had reached maturity, he was as misshapen a}

ascertain, if possible, the innediate cause of the dcrangencnt in question. They were begotten of a thick-bodicd, short-legged, muscular boar, whose sire was equally good, but in whose family, on the sidc of the female parent, there exists a predisposition to this cvilout of a sow of extraordinary worth, which $\mathrm{I}$ happencd to find in the possession of a man who, being little awarc of her intrinsic value, was readily prevailed upon to part with her. So profuscly was she covered with bristles, that, but for her briglitness of skin, and lightness of bone, she would have been accounted coarse. Her courage was sucl that, whilst in my hands, few men dared to approach her; and this property, associated as it was, with unusual capaciousness of chest, conferred upon her, what it ever will, a vast amount of flesh. Thus constituted, I had little hesitation in predicting that she would command the physicai character of the offspring; and the anticipation was further justified by the circumstance of the boar, to which she was put, having had a greater number of female visitors, for some days previously, than was compatible with a maintenance of his native vigour. She produced thirtecn pigs, after her own fashion, one of which died at birth-and two she subsequently lay upon. For though an cxccllent nurse, she could not always dispose of herself to the advantage of hcr young-her weight being computed at twenty-five stones, independently of offal, at the time of farrowing. And it is worthy of mention that, of this weight, shc lost not a stone in suckling ten pigs, with almost unexampled liberality, for the space of nine wecks-a circumstance I have never before known to occur, under any treatment, and which can only be explained, by reference to that uncompromising nervous faculty which, in addition to other services, promoted the most perfect digestion of all she ate. Her offspring, though individually small at birth, grew remarkably fast, as do generally those which are descended from vigorous parents; and at eight weeks old I could have sold them for a sovereign cach. But I wished to learn whethcr I could superinduce, by errors in diet, such a disordered state of the general hcalth, as should impair the integrity of their figurc. 'They had hitherto been fcd judiciously; but now their appetites wcre sated with redundant incals of rich and inappropriatc food. 'The vital power was thus unfairly taxcd; and soon, instcad of warring with each other, as they had previously dunc, they slunk, with tumid bellies 
brute as any $I$ have seen in the possession of a distinguished breeder. Still was his quality good. The cellular membrane (which butchers inflate in the dead calf, to give a seeming plumpness to their veal, and which furnishes a nidus for the deposition of fat) was every where so abundant as to impart to the hand, when passed along his sides, a sensation like that which results from the handling of blubber. But that was nearly all,

and uplifted loins, into their bed. Uneasiness forbidding an cxtcnsion of thcir limbs, a posturc, common to the kangaroo and rabbit, was assumcd: they crouched upon their haunches, and bewailed, soinctincs, in pitcous tones, their sad engorgement. A penalty attached to indigestion, in awhile, obtunded their desirc for food; and whether standing at the trough, or, in disgust, retiring, therc was manifested an instinctive effort to relax the coverings of the belly. Suspecting sub-acute or chronic inflammation of the visecra, I purposely killed one, when numcrous contractions of the small, and some, too, of the large, intestines, consequent on inflammation, werc unvciled. The hardicst of the litter suffercd most from intestinal mischief: those which inclined to premature obcsity, gave evidence of scrofula. The flesh they once enjoycd, becane, in part, absorbed, and morbid fatncss followed. Increasing pallor marked the surface; and that portion of the spine which, in rude health, cxtends a kindly arch along the chest, fell in, and neccssarily restricted, in their play, the vital organs. Thus was a latent disposition to diseasc provoked to active cxercise: for though in form and constitution, all the family submittcd to experiment were good, no sooner wcre they, by the means employed on many a farm, to expedite the growth of favourite animals, rcduced to that condition which belonged to the more dclicate of their ancestors, than the discase with which such weakncss was associatcd, superrened. I dare not, in a notc, alrcady much too long, pursuc the subject further; and will, therefore, learc thesc observations to subserre, as best they may, the individual applicition of ing readcrs. 
beyond common integument, that covered his ribs; whilst his flank was considered, as well by his owner as myself, to be the heaviest we had known-so partially was his carcase clothed. His habit accorded more nearly with that of a cow than of a bull: he had, therefore, not long fulfilled the obligations of his sex, before chronic visceral disease arose; and the case proving hopeless, he was eventually destroyed.

These two examples of defective vigour I adduce, for the sake of showing the desirableness of keeping in mind the characteristic distinction of the sexes. Extreme futness belongs not properly to the masculine gender. Men of that class are rarely endowed with the power to serve themselves in emergency,-nay, they are hardly fitted for the discharge of ordinary duties. If they attempt to prosecute an idea, oblivion soon its respite brings : under bodily labour they perspire and flag most pitifully; and not unfrequently, whilst the consummation of venereal intercourse is yet in prospective, are they tranquilly absorbed in sleep. And the law which applies to them is of universal prevalence. A disposition to secrete fat rather than flesh, implies weakness, in the first instance: for the highest point to be gained in assimilation, particularly with herbivorous animals, 
whose food contains none of that chemical constituent (nitrogen) with which muscle abounds, is the conversion of aliment into flesh; and those which fall short of an ability to do that well, can make fat, in as much as a conspicuous chemical element of such product (carbon) exists abundantly in vegetable matter.* And when any animal, originally, somewhat faulty, becomes loaded with fat, the nervous system is exercised in so high a degree, to preserve vitality, that no extraneous effort can,

* The arguinent still further prosecuted, will show why horses are disposed to grow flesh, out of all proportion to fat, as compared with cattle, sheep, and pigs. Their irritability, exceeding that of the other animals I have named, prompts them to morc vigorous cxcrcise: that induces a full and perfcct respiration, which, next to food, is the most valuable agent in the maintenance of irritability; since it not only liberates the carbon acquired by the blood, in its circulation throughout the system, and on the retention of which, stupor, and a corresponding tendency to fatncss would be incurred; but it charges the blood with an atmospheric principlc, consisting mainly of nitrogen (a property intimately identified with flesh), and fits it the better for depositing muscular corpuscles. In the present state of physiological science, the functions of respiration and cntancons imbibition are but imperfectly understood; but of their availableness to the purpose of nutrition, we need require no better proof than is furnished in the uniformly rubicund, muscular, character of butchers. 'To birds we may also apply the same reasoning. Their mobility is owiug to the cxccss in which nervous irritability prevails. They have a rapid circulation, and require a large pulmonary apparatus to purify the blood as it flows: hence they are provided with lungs capacious in comparison of the entire animal bulk; and so admirably does this conjoint dispensation serve the interest of the feathered tribes, that, whilst it affords them the utmost facilitics for converting grain into flesh, in the ordinary process of digestion, when food is plentiful, it enables the n to cndure the multiplied ills inflicted by the prevalence of wintry storins. 
in safety, be indulged. So surely as it is imposed, as in the harass to which human subjects of this class are occasionally subjected, paralysis, apoplexy, or some formidable disease, is the consequence. Thus do we learn why bulls of the character I have been describing, and even those of still greater robustness, when pampered, are slow to serve cows, and beget a feeble offspring at best. Unlike the bloated publican, who nerves himself to the task by artificial means, the bull has only his native energies, sustained as they are by natural food, ${ }^{*}$ air, and exercise, to depend on :

* The subject of feeding is one of such vast importance to the farmer and breeder, that I cannot forbear to indulge once more in a few passing remarks. Food is the natural stimulus to the stomach, and is provided by Nature, not simply to gratify the cravings of hungcr, but to repair, in the viltimate process of digestion, the waste to which aninal bodies are subjected, in the inaintenance of vitality. Instinetircly do those elasses which come not under the control of man, as does inan himself where civilization is unknown, seek the kind of alinent to which they are expressly adapted by the Great Author of their being; and no appropriation of them to donestic purposes ean he profitably conducted which is not based on an attentive consideration of their constitutional peculiarities and habits. 'Thus cattlc delight exceedingly to graze on old established pastures : and observation, dircctcd to the faet, is not long in determining that the passion owes its rise to the healthful variety in which the natural grisses are intermingled in such fields, and to the consequent facility afforded for the gratification of individual taste. 'J'he ealf, which has scarcely yet been pratised if the art of assinilating vegetable matter, lingers awhile o'er eaeh inviting plant, and crops the fairest; whilst those of more ripened form tear off the rampant blade, and season the neal with spices drawn from aerid somrces near. 'I'lue most aviilable of 


\section{a greater error can, therefore, scarcely be com- mitted (and it is one into which men are very apt}

these cordial resources are the several species of ranunculus (crowfoot, or butter-cup, vulgarly), and the leaves of the earth, or pig-nut (bunium bulbocastanum). In spring, when the grasses are extremely succulent, these aromatics possess a pungency little short of the inustard of commerce; but as they advance to maturity, they lose this property, and, by drying, it is entirely dissipated. The design to be fulfilled in these mutations is clearly discoverable, and is worthy alone of Him whose are "the cattlc on a thousand hills." The tendency of succulent vegctables, that partake not of an aromatic principle, to fermentation, when exposed to a heat like that which they encounter in the living stonach, is so great, that, befure the work of runination can be conducted, there is an evolution of gas which defies its further progress. Stimulants possess not only the power to suspend fermentation for some time, but to quicken the stomach in the discharge of its common duty. And of this herbivorons animals are so well aware, that they will consume just so much crow-foot as is necessary to obtain for them an efficient digestion. 'I'hey commonly eat most before retiring to rest at night, and, as if to throw off the lassitude engendered by repose, when rising to rcnew the task of providing for the day. To me it has often afforded interest, to watch their operations at such times. If a scarcity of the plant occur where a beast is feeding, she soon repairs to another spot; and if she happen to seize more than is wanted to impart the required flavour, by a dexterous manœuvre she conducts that which is dispensable to an angle of the mouth, and thence lets it fall. As vegetation ripens, its watery particles give place to fibrous matter: the probability of fermentation, therefore, is diminished; and, of course, less condiment is needed for protection. Hence the several families of the ranunculus are losing their virulence at that period; and by such time as grass has been converted into hay, they lave taken on the character of bland, nutritive, products, that may be eaten without intermixture with other licrbage. Wc learn, then, in the school of Nature, that, in providing those substitutes for the natural grasses, which improved husbandry enjoins, as well with a view to the interest of the soil, as to that of the stock which subsist thercon, we ouglit to sow conjointly with clover, lills, \&c., the sced of crow-foot, or of sumc plant cqually stiunulating. For want of this precatution, the effects of young clover on cattle are olten 


\section{to fall), than to select a male, because he has a thin, soft, skin, adorned with fine, silk-like hair,}

very distressing, though not inore so than would result from the use of spring grass, without the generous intervention I have alluded to. Unfortunately, the mischief occasioned by a liberal employment of insipid, juiey, vegetables is not confiued to the stomach and its assistant viscera: the nervous system, and, consequently, thc cntire animal economy, sustains a sliock, and that to so great an extent, that it is no uncommon occurrence to find originally vigorous males emaseulated by the debilitating aetion of such food; and, as though in anticipation of injary, l have seen, on one farm, five bulls stand emptybellied, at the close of day, having each a manger well furnished with clorer, on being denied any longer a feast of eut grass. An apology for the absence of aroma, in the substance of turnips, is found in the biting qualitics of their rind; so that an inflation of the rumen, in a beast, otherwise healthy, that is being fed upon turnips, is seldom to bc heard of; whilst those to which a daily allowanee of potatoes is awarded, are commonly made sufferers from that cause. Twice has this disister befallen a cow of my own, from the employment of potatoes, beyond the extent to which they had been prescribed; and onee I nearly lost a valuable ealf, at six months old, by giving it about a quartern measure full, with a view to their aperient operation on the bowcls. Flatulent eolic ensued, which was with difticulty relieved by aromatics, anodyncs, and a temporary clothing of flannel.

Unless they be sparingly adıninistered, potatoes, when even boiled, will purge young pigs exccssively; and may do more harın, by that means, in a few hours, than well advised treatment can atone for, in as niany days. Pcrlaps the best mode of obviating their laxative tendency, when given to pigs in a cooked form, is to eombine them, as custom sanetions, with somc warm farinaceous matter, derived from grain, as barley flour, with the addition of as inuch salt as is required to impart an agreeable flavour. Without some corrective, the propriety of livishing potatoes on pigs may be very gravely questioncd. 'I'licy are not a root on which these animals subsist, in a state of nattive independency; nor have they the properties in common with those regetables for which pigs liave tlie greatest relish, as eartli-nuts, clicsnuts, acorns, \&c. These products have all a sweetish, sub-icrid taste, and possess more or less astringency-al circumstance alluilably adapt. ing them to the constilutional demands of the amiunal, which are at 


\section{and is well provided with fat upon his hips and rump. For since it is undeniable that the basis of}

variance with relaxants generally. I have long suspected the sow's wilk to be slightly astringent: it conveys such impression tomy own taste; and the remarkably constipated condition of the heal thiest sucking pigs, would still furthcr appcar to warrant the supposition. My argument that potatoes, in the abstract, are not well suited to the temperament of pigs, rests not merely on the little affinity they bear to those articles which the animal prefers to live on: it gains considerable strength from the manner in which raw, unwashed, potatoes are treated by pigs. If they be thrown down to one accustomed to such food, and their size admit of being received into the moutl entire, he takes up each in turn, and rolls it lightly over his tongue, by which ineans any little eakes of dirt that may be found adhering, are dislodged and ejected by the moutli; at the same time that this action excites an immediate and profuse flow of saliva, with which the chief of the remaining dirt is literally washed off. The potatoe is then consigned to the grinders; and much of its juice having been first allowed to eseape, the remainder is swallowed along with the body of the fruit. Now why this instinctive elaboration, bcfore committing to the stomach, what, as an artiele of food, is almost universally thought to be applieable to him? Not the cleanly habits of the animal, which forbid an intermixture of siliceous mattcr with his ingesta. 'The presence of grit would seem to bc essential to a healthy aetion of his stomach and bowels; and it is often eagerly sought, in the form of enal, einders, sand-stone, \&c.: but thc combined influence of a cold, watery, vapid root, and its encireling earth, is morc than he can profitably entertain; and with a tact, therefore, which would appear to denote a glimmering of reason, does he reject all that is truly superfluous. This seeming distaste for unsavory food, which is borne out by the greater avidity with which a pig will eat applcs, lettuce, and the pods of green peas than those of broad, and French, bcans, or even cabbage, should suggest to our minds, particularly when taken in connection with the impermcable character of its skin, the impolicy of administering its food in a very diluted form. But I must conelude this article: already has the interest attached to the subject led me to trespass on the patienec of my readers further than I liad contemplated in the outset; and enough has surely becn said to prove that, if we are to excel in the management of inferior animals, we must elosely study the constitutional peculiarities and habits of those we engage to treat. 
animal usefulness consists in a possession of due nervous irritability, the breeder's interest obviously lies in the choice of such as combine this attribute with a beautiful arrangement of bodily structure; and not once, out of twenty instances, will he find the features I have recently enumerated, in connection with extreme nuscularity and good courage.

The inertness which I have shown to be constitutional in males, whose disposition to obesity is in excess, supervenes on even the most vigorous, if applied to the purposes of procreation, beyond the period allotted by Nature, for an efficient discharge of that function. To compute, by time, when males of any species should be withdrawn from service, would be impossible; since those which are entitled to rank in the first class, will differ materially in their powers of endurance, under like treatment. And when to this original difference, is added that which individual management involves, the difficulty of proscribing an animal, in justice, on the score of years, will be obvious enough. Indefinitely, it may be said that the close of usefulness in a good bull, ranges between the seventh and tenth years of his age,and, in a boar, between the third and fifth. But 
the only correct mode of settling the question, is by reference to the manner and appearance of the animal employed. If he be one of high, and just, pretensions-say, a bull, and have been suffered, as most assuredly he ought, from his birth upwards, to carry as much condition as is compatible with activity and cheerfulness, he will be found about the fourth or fifth year, probably sooner, disposed to fatten more than formerly: where little beyond flesh has been felt aforetime, fat is now discoverable. In those of very high courage, that are somewhat difficult of control, this period will be protracted yet further; and about the sixth or seventh year, a degree of ripeness, unobserved before, will arise. It now behoves his owner, provided that he still wish to retain him for procreation, to notice in what mood he entertains the other sex. If he look with comparative indifference on a cow in season, and refuse, for some time, to answer the call of his attendant, the vital. principle is being consumed as fast as it is engendered, in the maintenance of his carcase, and none can be expended in propagation, without endangering the issue.

The case is not unfrequently paralleled in those of our own species, - as when a man of good con- 
stitution, at fifty, grows lazy and fat. The intelligence he once possessed begins to desert him; and all other faculties, dependent on nervous irritability, in like manner become blunted-until his energies proving insufficient to command a healthful state of mere animal existence, visceral disease makes inroads on his frame, or one of the more frightful forms of nervous affliction removes him from the living. And instances are not wanting in the class of animals to which my observations more immediately refer, to make the parallel complete. The celebrated bull Shakspeare, of the long horus, is reported to have fallen a prey to paralysis, when ten years old; and Earl Spencer's bull Firby, rendered deservedly famous by the notice he has received in the Society's popular treatise on Cattle, was the subject of incipient paralysis, at about the same age, when I saw him at $\mathbf{W}$ iseton a few years ago.

To guard against a seizure of this kind, in the subject before us, the most valuable agents in the preservation of nervous irritability should be had recourse to. Daily exercise, proportioned to his strength, away from home, so that his attention may be directed to fresh objects, should be enforced; and a diet, somewhat more stimulating, but less nutritive, than that to which he has 
been accustomed, should be chosen. If, under such treatment, his bowels remain torpid, and his dung preserve an immoderate consistency, the proprietor may rest assured that his symptoms augur badly. He is yet too enervated to admit of being advantageously employed ; and along with an occasional purgative, the best of which, in his case, is croton oil, bleeding may be instituted, provided that the jugular vein can be got at. Should these means succeed in restoring the tone of the system, he may be introduced afresh to cows, taking care to premise that they are shown to him in a situation remote from that in which his interviews have been previously conducted; so that, if possible, a new and more pleasurable train of association may be established. But should the lethargy continue, in spite of all efforts at redemption, it were better that he be consigned to the butcher, than that additional pains be taken to bolster up a declining constitution. For I care not what may be his appearance: he may look as he did when younger; yet will his stock inherit more bone than formerly, and be otherwise devoid of beauty. In the season of earlier growth, when the work of animal deposition, absorption, and rearrangement is fast progressing, the institution of a generative faculty is withheld: but the model- 
ling and perfecting of the system having been, for the most part, accomplished, the flame of venereal passion begins, and continues to burn with ardour proportioned to individual temperament, and the force of exciting causes, till fleshly incentives lose their charm, and infirmities announce that the proudest characteristic of the sex is fading. Indeed all nature attests that to life belongs a constant succession of changes, involving either physical developement or decline; and it is unreasonable to expect from an individual, when the tide of vigour is receding, those services which were once efficiently bestowed.

I know, from extensive dealings with agriculturists, that, on this point, I shall be found to differ from many supposed authorities. It will be expected; therefore, that I shall support my opinion with proof. I will do so. A very distinguished breeder of my acquaintance purchased at Mr. Mason's sale, a three-year-old roan bull, of singularly fortunate shape and quality, which, on account of his rare merit as a stock-getter, he kept upon his farm six years.* When contem-

- I have here, unfortunately, to contend more with individual prejudice than with the difficulties attachable to my subject. If I publish the name of my friend, in connection with the following detail, I shall offend him: and whichever way I turn, an objection is 
plating his destruction, I put to him a light-fleshed cow, of mild, languishing, countenance-just such a beast as might be expected to impose on the bull an ample share of generative responsibility And that this was, indeed, her custom, is proved by the fact, that four calves which she bred, whilst in my possession, were all males, and partook mainly of the character of their sires. On the occasion I allude to, much difficulty was experienced in coaxing the old bull (for he was very heavy withal) to fulfil the office assigned to him. Eventually this was accomplished; and in 282 days the cow produced a big, clumsy, ill-shaped, bull calf. To rear him I knew would be to incur a very serious cost, in the heart of a manufacturing town, where all landed commodities fetch an exorbitant price. Besides, I had engaged, in addition to the first charge of two guineas for bulling, to pay five more, in the event of a male issue that should be appropriated to masculine

raised to the announcement of facts that can, by possibility, be construed to the disadvantage of those who are personally interested in them. It is this dread of fair discussion that has tended, more than any other cause, to check the diffusion of practical knowledgc. I regret its prevalence; but having no intention to abuse the privilegcs I have long enjoyed on the farm of the gentleman in question, I must le'g the rcader's acceptance of this, and a few subscquent, illustrations, in the disguised form which 1 feel compclled rehuctantly to adopt. 
purposes. As experiment, however, was my object, I considered that the money I should thus lay out would be well applied, and undertook therefore, my task in good spirit. From the period of his birth (November) to the ensuing May, he was confined in a shed with his dam, and allowed, so soon as his wants impelled him, to take all the milk she secreted; and in the exercise of that function she had few rivals. They were then, for three months, both turned into a rich field of an acre and a half, where no intrusion on their retirement occurred, save that which arose from a morning and evening visit, paid to them by myself, with as much regularity as opportunity would allow. The calf was now weaned; and at the end of fifteen months, he was introduced to a few corvs. Shortly afterwards I castrated him; and having grazed him during part of the following summer, in Wilford pasture (a piece of rich feeding land, provided with a stream of good water), along with eleven cows, I submitted him to slaughter.

It may excite surprise that I should have resorted to this alternative, instead of keeping him entire, or selling him in that state for the benefit of another, after incurring so much expense in the first instance. My reason for so doing was founded on a belief that he would be no valuable acquisition 
to a purchaser, though preferable to scores I have seen in the hands of English farmers. I reared him not from any fanciful or misconceived notion of his importance, but because the contemplation of his figure and history tended to establish many views I had entertained on the subject of breeding. His faults, which were obvious at birth, "grew with his growth," and afforded a memorable proof, in addition to many others I could adduce, of the impracticability of maturing a good beast from an originally defective calf: His issue, again, gave

This observation applies no less to a calf of high-sounding pedigree than to one of professedly mean birth. Function is an inherent and essential attribute of structure; and, in health, one stands to the other, in the relation of effect to cause. A defective form, then, whether generally or locally considered, involves, in the abstract, a correspondingly defective action; and though that subtle agent which we recognize when speaking in terms of "nervous," or "vital influence," "spirit," "pluck," "mettle," \&c., may serve to give efficiency to what would otherwise be reckoned wholly, or, in part, of little worth, it never can invest a faulty animal base with much flesh or fat, or correct errors arising from local imperfections of structure. Practised dealers, in conducting their purchases of stock, are always fuund to bear ample testimony to the truth of this remark; and to tcll one of them, when offering a cow, or a horse, of contracted chest, for sale, that it will acquire robustness, on being introduced to "good leep;" or tlat a liabit of "cutting," in the latter, has becn contracted by lad shoeing, is to incur the certainty of being laughed at. Il is only when engaged in selling that he adopts those vicws. The policy of such men affords a remarkable contrast with that of another cliss, who, withont any well-digested ideas of structure, deem every animal of great value that is reputed to be of good descent. I remenber secing a young bull in the possession of $\mathrm{M}: \mathrm{W}-$, of $\mathrm{E}-$, in this connty, when that gentleman was attempting, a few years since, to cultivate short-liorned cattle, that was much admired by many; and 


\section{authority for much that has fallen from me in con- demnation of bulls which, though once good,}

being asked my opinion of his merit, I referred to his general want of room in the ehest, as indicated in the precipitate descent of the ribs, and indented fignre of the plates, which allowed the elbows to retire, and the shoulder points (humero-scapular articulation) correspondingly to protrude, in support of an intimation that he could never earry a great quantity of flesh, and eould, therefore, contribute little to the reputation of a breeder. Sn soon as he could brave the shoek inflieted by this unexpected announcement, the man in eharge of him begged to submit that, though my theory might deservedly apply to cattle of meaner origin, it could liave no weight in respeet tu the one in question, whose dam had been purehased at a very considerable sum, purely on aceount of her exemption frum intermixture with base blood. Besides, added he, with the eharaeteristic simplieity of inexperienee, the imperfeetions to whieh you allude will be no longer discoverable, when the bull shall have attained mature growth. At present he is young, and, possibly, wanting in the girth ; but see him again in a twelvemonth, when he shall have had some good keep, and you will hardly know him. The pratical authority will here discover that this poor fellow echoed the story told, in extenuation of a bad form, by every norice, whose observation has not taught liin that a calf, at any period of its age, under a generous diet, presents an accurate miniature representation of the full-grown beast,that the proportions manifested in early life advanee pretty uniformly with each other throughout the successive stages of developement; and that, consequently, what appears to be a trifling defeet at first, assumes ultimately a much more objectionable character. The owner of the bull to which I have just adverted, refused to take 50 guineas for him, when a few weeks old, of a gentleman then about to engage in a like pursuit, though intrinsieally worth no more than $7 l$. when I saw him at the age of six months. A ginger-coloured bull calf, abont a fortnight old, without one good property, I remarked, at the same time, to be worthless, except for the amount of veal it might furnish, and adrised its being set apart for that purpose. "Olı!" I was answered, "it would not do to dispose of the breed in that manner; in eolour this calf resembled the fanous bull "Hubback; and if well reared, he might possibly beget as good stock." 'To all "pure blood" irlrocates I would sily-"pedigree" descrves only to be regarded so long as the "mities" are well maintained. 
shall have become venerable by time; for they were all "weedy," and had they been otherwise, they must have owed their merit, remotely, to his sire, since his dam was of mean extraction; and every cow to which her son was put was equally so, being the property of poor milk-men of the town. Lastly, I would observe, that the sexual privation inflicted on this young bull, enabled me to determine why the operation should be performed before the generative faculty is attained to. When, afterwards, he was allowed to roam promiscuously with cows, his custom was to companion one awhile, and mourn with her, in silent converse, the ills that had been perpetrated on him.

Her'sympathies enkindled did but serve

To swell his anguislı; for whilst favoured tlus, Assoeiate joys would vividly reeur,

And, prompting weak and impotent desires,

Provoke the steril repulse-

Unless proud Nature slould, in fitful mood, Have fired the heart with keen erotie glow,As when the genial slowers profusely fall, And rise like incense o'er the fertile mead:

Then would his suit be rapturously embraeedAnd if not uuremittingly pursued, Insatiate lust would goad him to the task, 'lill foreed into submission, or eompelled 'T'o scek repose beneath the distant shade Of friendly lawthorn. 'Thither would he steal, Preferring to begnile the tedious hours In inoody solitude, than stand the brunt 
Of unrequiterl love. Constrined by want,

At lengtl to nove abroad, his loitering step

Marked first the boundiug fenee, on whieh he liruwsel:

Then daring, softly, to approaeh the herd,

He joined in their repast. Sometimes, at once,

And less involring coyness of demean,

Would friendship be restored. A eommon foe,

Announced in latrant tone, or piercing dart

Of swift-winged œstrus, ${ }^{*}$ would soon reconcile

* Few cugagements afford so much solid instruetion as that which seeks to deteruline, by reference to the instinetive operations of animals, the purposes they are designed to answer in the boundless economy of Nature. Every elass is appointed to the diseharge of a speeific function, or otherwise eontributes, to the promotion of inan's interest, without exeeption, even, to the eountless tribes of insects, that load with atomie life the vernal air. Yet not unfrequently does it lappen, as in the instanee of the gad-fly (cestrus bovis), that eomplaint is made of those to which we are largely indebted. By sueh time as this little animal emerges from its ehrysalis, in the form of a fly, the grasses liave, for the most part, ripened, and the cattle thereon are thriving with a rapidity that endangers health. Their stomaehs being quiekly filled with available food, repose is sought: but now alights the female ostrus on the baek of one, which throws the whole herd into eonfusion, and away they start in the vain hope of eseape from their assailant. All this while does their troublesome visitor proeed from one beast to another, piereing them where best she ean avoid the lashing of their tails, and depositing, in each puneture, the germ of a future inseet: and thus is congestion obviated, which, in the most plethorie of these animals, would be pretty sure to supervene on habitual quietude. The scason passes over'; and the gad-fly, having executed its mission, dies on the field where, in transport, it has lived. Winter comes; and the risk of repletion having deelined, " the lowing herl wind slowly o'er the lea," exposed, in no wise, to foreign aggression. But on the approach of spring, the embryon insects, which have hitherto been nurtured with little or no inconvenienec, advanee rapidly in growth, oeeasioning uneasiness, and a frording indications of their seat in noduli, disposed along the sufferer's' hacks. Presently the cattle are turned to grass, when a vast acces- 
The angry pair (as will a neighbouring fire, 'That threatens to invade our peaceful home, Bring those in friendly contact who, for years, Have been estringed), and blend, in common cause, 'The startled herd, to fly, or to defend

Themselves from harm. Or haply, whilst in dudgeon

He remained, the season for refreshment

Would arrive, when, following in the rear

Of those whom Nature summoned to the feast,

Might he be secn, intent (as oft is man,

In draughts less pure) on finding from all ills

A sweet release. Another trealy formed

sion of nervous vigour propels the blood universally to the surface, and stimulates every organ to redundant secretion. In so far as the viscera are concerned, this additional labour is comnonly well sustained. 'The part inost endangered is the cellular, or sub-cutaneous tissue (on the comparative amomt of which we determine the capacity of an animal for fittening), and for this reason: it is but scintily endowed with nervons sensibility; and, when urged, in common with other structures, to excessive action, the balance between secretion and absorption is soon lost, and an accumulation of serum follows. In other words, inflammation-precisely similar to that which we witness in lymphatic subjects of our own species, when addicted to irregularities, is the consequence. But now comes into view the remedy provided ly nature in this case. The larvæ are all deriving support from the cellular tissue, independently of the irritation they individually ristablish; and by thus serving as diverticula for the exuberant animal juices, they preserve the subjects of local inconvenience from constitutional injury: A conviction of the benefit attached to this bountifill institution led men, no doubt, originally, to introduce a seton in the rlew-lap, on turning out, to spring grass, cattle that were free from warbles; and the custom has been very judiciously perpetuated flown to onr own time. Throngh non-observance of it, I once lost an excellent calf, and should have lost also a cow, but for the timcly employment of free incisions, after the inamuer advised by $\mathbf{M r}$. Iawrence, in crysipelas of the human subject. I would just add - it is on the same principle that medical men practise connter-irritation, in form of scton, issue, \&c., both in a curative, and preventive, sense. 
Was but the harbinger of future woe:

And thus one coustant, ever varying, round Of pain and pleasure, robbed him of the flesh He once enjoyed, and inade him barely ineet For human food.*

In a few days after the bull, whose history I have just given, had been conceived, a public sale of short-horns, the property of Major Bower, of Welliam, in Yorkshire, took place. The circumstance of this gentleman being known to have started with cattle derived immediately from Charles Colling's stock, together with the extensive publicity given to the intended sale, secured an attendance of many distinguished breeders and admirers of short-horns. They had, however, the mortification to learn that the animals submitted to competition were, by no means, worthy of their predecessors, or of the representation made of them, by advertisement and circular. The

* An apology is, perhaps, due, for having related in verse what, some may think, would have been far better told in prose. I assure all who shall demur that, if I eould have net their wishes, I should have been glad to do so. For two days I attempterl a simple prosaie narrative, but alwalys sunk beneath the subjeet; and was at length compelled, in ny desire to avoid vulgarity, to adopt a more lofty style. Anrl now 1 am disposed to believe that several passages, involving extreme delicacy of sentiment, would have been inore appropriately given in a like inammer. The only objeetion 1 ean discover to such a course is- that the work might have been rendered somewhat less generally intelligible than in its present form. 
principal buyers consisted of gentlemen about to embark in the practice of breeding; amongst whom was one from the neighbourhood of Nottingham, who, having possessed himself of nine or ten cows and heifers, at prices, varying, I believe, from eleven to thirty guineas each, returned home with a determination to purchase the best shorthorn bull he could procure. Regardless of age, he bought the animal to which my cow had just before been introduced-already slow to cover, as previously intimated; and now rendered still more inert by change of residence and custody. Occasionally it was found necessary to send for his former attendant, before a cow could be served; whereupon his proprietor resolved to reduce his weight, then amounting to 164 stones. This was accordingly done, to the extent of about 20 stones, without effecting any material change in the bull's disposition. Indeed the work of deterioration, which had been for some time past in progress, was thus well nigh consummated. He was no longer what he had been, either in physical bulk or in spirit; and though not absolutely "powerless his kind to gender," how was he to communicate to his posterity properties which, in himself, had fallen into decay? Animal bodies are all resolvable into elementary particles, whose indi- 
vidual bulk preserve a just ratio to the texture they compose, and the magnitude of the system with which they are identified.* 'Thus, the ultimate corpuscles of muscular fibre (which consist of the red globules of the blood, under some slight modification) vary with the size and condition of the subject, and the application of the members to which they respectively contribute. They are bolder in the larger class of animals than in

* 'Throughout nature it is observable that the eomponent particles of matter are minute and lense, in proportion to the searcity with which they are dispensed-and vice versa. In so far as animal organization is concerned, such arrangement is productire of immeasurablc advantages. The faeulty of prehension, for instance, dcmands a lightness and mobility of the members exereised, along with a power of resistance equal to that employed in their direction. These requisites we enjoy in the construction of our hands and feet-assoeiating as they do, by means of ligament, a numerous phalanx of small boncs, to which are distributed, apparently delicate, but powerful, tendons, equivalent to the task imposed on then by the flexor and extensor muscles, whose interests they subservc. In the membranous expansion, moreover, by which the muscles are kept in situ, during their most vigorous contraetion, the prineiple is exemplified; as also in the greater hardness of small, than of correspondingly large, bones. The skin enveloping the extremities of eattle is another illustration. It is thinner below the knee than on the neck-but is far less permeable to moisturc; though yielding more readily to the knife, for the reason that moderately hard substanees are more easily aeted upon than are those of spongy charaeter. In the vegetablc kingdom the same law obtains. Trees that are of rapid growth, as willows and pines, are of looscr texture than sueh as are slowly matured. The stunted hedgerow oak is harder than that whieh grows in fellowship with others. The mineral kingdoin furnishes additional cxamples. Iron, which is plentifully discovcrable, is more porous than silver, silver than gold, gold than platina. 
smaller of the same species, as, by the same law, they are bolder in one part of an animal than in another. Hence the preference due to a Scottish bullock over our boasted short-horn, and to Southdown mutton over that of Lincolnshire; as also to a sirloin of beef over the neck or shoulder of the same beast. And as by primitive constituents, so by ostensible products. The semen is a type of the entire system; and I doubt not, if that which was secreted by this bull had been subjected to microscopical investigation, both before and after his loss of flesh was sustained, it would have been found to differ considerably in character. And so exactly did the result of reproductive exercise comport with the description I am giving of his infirmity, that, though reputed, in his earlier days, to have begotten some of the finest stock in the kingdom, he did not get, when put to ordinary cows, one truly good calf, during the two years this gentleman kept him. The speculation failing, he was sold by auction, along with all that had descended from him, whilst on this estate, and shortly afterwards died.

Less fortunately for $\mathrm{Mr}$. —_ than for the interest of science, his place was supplied by another

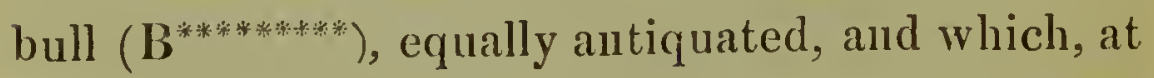
no period of life, lad possessed the constitution of 
the former. He was hired for twelve months, at a considerable cost; and as he was well known to many breeders of the North, and greatly approved by some, it may not be amiss to state, in this place, the ground of my objection to him. He was extravagantly large; and, like most huge animals, wanted symmetry. His skin was soft and thin; and his hair excessively fine and silky in appearance. Of cellular membrane he had a profusion ; but of flesh he had no more than was needed to conduct so large a frame through the mechanical duties attached to his position on the farm. Originally he had more : though I contend that his muscularity never could have entitled him to rank with those of the first class-his habit inclining rather to a secretion of fat than lean. The high price at which he was let, together with the sum for which he was sold, at the conclusion of his engagement with Mr. - - would, I am aware, hardly seem to justify the opinion I am giving. But such considerations weigh lightly with me, when opposed to the authority of physiological truth. There is too great a leaning on the part of breeders to animals in which fat superabounds; and $I$ have known them often to indulge their prejudice, at a greater outlay than has been commensurate with either their own or the public interest. Whether 
the attenuated form in which this bull was imported to - - was the result of natural decline, or of human contrivance, I know not: but conscious of the disappointment that his introduction would occasion, I endeavoured, in so far as prudence would allow, to dissuade this gentleman from using him. My efforts, however, were unavailing : having engaged the animal's services, he determined on submitting them to trial ; and ill indeed did the experiment reward him. The vital principle was so sparingly bestowed, that few calves survived their birth many hours; and those which lived yet longer, had little to recommend them to notice.* This last, and signal, failure induced Mr. - - to relinquish a pursuit, in which he had profitlessly embarked several thousand pounds. For it is worthy of remark that, during the few

* The reader will perceive how well this result justifies the caution given by Virgil in the followiug passage, which, though having immediate reference to the stallion, is no less applicable to the bull:

Frigidus in Venerem senior, frustraque litborem Ingratum trahit: et, si quindo ad prelia rentum est, Ut quondam in stipulis magnus sine viribus ignis, Incassum furit. Georg. iii. 97.

For when his blool no youtluful spirits move, He languisles and labours in his love.

And when the sprightly seed should swiftly cone, Dribbling he drudges, and defrauds the womb. In vain he burns like hasty stubble fires; And in himself his former self requires. 
years he was thus unsuccessfully occupied, he made very extensive purchases of cows, at prices, varying from those at which he started to 220 guineas, each, some of which were put to this bull : but, as though by common consent, they imposed on him the entire procreative responsibility; and he discharged his function in the manner I have just set forth. Here, then, is the evidence on which I establish my objection to the use of bulls whose constitutional energies are on the wane.

I have intimated above, that ex travagantly large animals are rarely symmetrical; and having previously maintained that functional integrity prevails only in a degree corresponding to that of structure, whether viewed in a general or local sense, it follows that very large males are not the best adapted to purposes of procreation. To prove it, I must invite attention to the fact, that the nervous principle which pervades and governs animal bodies, is active in proportion to the supply originally conferred, and the extent of exercise which it is called upon to endure. If, then, two bulls inherit, each, a like quantum of nervous vigour, and one attain to a much larger size than another, the larger will preserve an habitual sluggishness, and the smaller an habitual activity. 
The superintending power which, in one instance, is barely sufficient to keep every faculty in health, is, in the other, more than enough for the accomplishment of the same end. By imposing on this subtle agent an additional burthen, as by fattening him, or exacting from him an unreasonable amount of labour, the spirit of the little bull may be reduced to the standard of its fellow. But under similar treatment, he will command a more healthful condition of body, and be better fitted to engage in extraneous efforts.* An unusually

* Thus is it that we account for the fact that a man, weighing 16 stones, however hardy he may be, rarely contends successfully in the prize-ring against one that is somewliat lighter, - that the heary Lincolnshire dray-horse moves with more sluggishness than does the Suffolk puneh, - that the ordinary roadster steps in ore slowly than the Welsh poney,-and that even a race horse of the largest class strides with less frequeney than one of moderate size. 'There is so mueh nore nervous energy required, to enable the larger animal to direct its extremities, nnder the meehanical disadvantages incurred, - so much more, again, necled, to qualify the heart for propeling its blood to the extreme surface, and to conduct, in due order, the entire economy, that, were it possible for such animal, under pressing necessity, to maintain the quiek aetion of the smaller (their eonstitutional vigour being alike), the heart, or some important viscus, would lose its stimulus to exertion, and the sufferer, probably, fall deal in the struggle. 'Ihe force of this construction will appear the nore obvious after further illustration. I will suppose, therefore, a long, and a short-legged horse, of like spirit, and laving, relatirely, the same volume of chest, to be worked together. In performing his part, the long-legged animal will expend so mnch more vital principle than his companion, that, provided their labour he severe, he will scarcely be able to reserve enough, to eommand a healthful exereise of the natural funetions. Under circumstanees but little affecting the rigour 


\section{large bull, then, we commonly observe to fall short of the condition which even the figure of his trunk}

of the short-legged horse, he will quite fail to do so. An urgent demand on his services will deprive the stomach, in common with other organs, of its tone; and, until the various causes which contribute to the invigoration of the system shall have engendered a fresh supply, he will refuse his food, as we oursclves are accustomed to do, when the physical powers have been taxcd in too high a degree. In general he will eat more than his associate; for the greater "wear and tear" "incurred by him, will desnand of digestion a corresponding repair ; but owing to nervous insufficiency on the part of the viscera concerned in this process, a considerable portion of his food will pass through the bowels in an unassimilated form. So that whilst imposing on his owner a greater expense than the short-legged horse, he will appear in much the worse condition. A few years ago, a gentleman of Nottingham gave $40 \mathrm{l}$. for what he thought to be a promising twoyear-old, half-bred, colt, which he kept unemployed till four years old; and finding him then to exceed sixtecn hands, he deemed it al visable to take him to work. He now soon discovered his mistake. The horse could not travel five uiles without fatigue, though consuming an almost incredible quantity of corn. He was therefore sent to livery for disposal ; and none of "the trade" approving him, a purchaser was found at the sum of $16 l$. in the person of a bleacher, who employs him to draw a van in the neighbourhood. Experienced dealers are well aware of the danger of a half-bred liackney growing too big. "A nice horse that will make in a year or two," may sometimes be heard to proceed from one to another. "Aye,"-is not uncommonly the rcply; "I should like him if he does not grow into too much of a horse." There is a vast deal implied in that short colloguy: but I am again cxcceding the bounds usually prescribed to an illustrative note. I may, howcver, be permittcd to add that, if followed out in principle, the qucstion I have ventured thus liglitly to treat, would be found to involve inany interesting considcrations in relation to our own spccies. There are ficw localities inhabited by man, that do not furnish some pitiful instances of physical delicacy, as indicated in extravagant length and slenderness of limb. My aticntion was, in early lifc, greatly diverted from other and morc appropriatc studics, by a curious spccimcn that occurred in onc of two brothers, who journeyed with inc daily to school, about three iniles distant from the 


\section{would seem to promise, for want of more nervous energy to sustain the system, under the physical}

villagc in which we lived. He was a hungry-looking, long-jointed, lad, the very counterpart of "Noah Claypolc." Nor did his looks deceivc the most speculative observer" for hc could eat as nercr lad did bcsidc him. His mother was an indulgent creature: having provided a commodious recptacle for food, madc after the fashion of a domestic clothcs basket, but not quite so large, her next pleasnre was to fill it, whensoever its interior bespoke a neccssity for her doing so, which was once in twenty-four hours. The prevailing repast consisted of a "boiling" of potatoes, interspersed with fragments of bacon, which the youths prcferred to convey by means of a stick, to which their basket, with its contents, was suspended. It was always matter of complaint with him whose consumption excceded not that of other boys, that he should be compelled to carry half the provision; and he would endeavour, occasionally, to shove the basket handle beyond the notch which, by parental authority, had been indented on the middlc of thc rod. If foiled in the attempt, his next contrivance was to get in advance of the star rcling, and importunc him to come up with the load -a request which thc latter alwilys avowed the utmost willingness to comply with, on condition that he be first allow col the privilege of translating it to his own stomach. An insatiable appetite, however, belongs not to all of this class: and though bodily infirmity be their's, it is cominonly atoned for by the success with which they prosecute intellectual labours. Engendered not intempcratcly-but when neither animal nor nerrous faculties immoderately prevail, they inherit a disposition that fits them for calmly and patiently investigating whatever thcy undertakc to acquire. In inagination they rarely shine; but for research, and legitimate induction, they are pre-eminently distinguished. Men, so constitnted and excrcised, look with comparative indifference on women. 'The tidc of love, in thcm, flows not in impetuous streans: it faintly issucs-and, in many a pair, blights the fond hopc of marriage. To the same cause is the frequent cxtinction of the blood of mon to be referred, whose nervous excitability far transconds that of the class to which I have just alluded. Their energics are wholly, or for the most part, absorbed by thcir farourite study; and thcy disregard the oppositc sex entirely, or, at best, arc ablc to infuse but a trifling amount of rigour in to thcir offspring. Bacon, Locke, Newton, Pope, Swift, Hune, Gibbon, Cowpcr, Gray, Walpolc, Bolingbroke, 
disabilities attached to it. And exactly in keeping with this outward demonstration of weakness, is his inability to mature a healthful quality of semen. Of necessity, therefore, when taking precedence of the female in copulation, will his huge, spare, and ill-governed form be communicated to the offspring. In the event of his deferring to the female, an inheritance of his disposition, in some wise, will be likely to reproduce his figure in the next generation, as is continually being witnessed amongst ourselves. A child, answering almost exclusively to the personal character of one parent, marries; and the latent spirit of the unseen parent claims a restoration of his features in the grandchild. There are few exceptions to the rule which forbids the employment of very large males.

Whilst entertaining this question, it deserves to be considered how far relative disproportion of one sex to another, can be adopted with safety or advantage to the breeder. It so happens that established authorities are directly at variance on the point. Mr. Cline, whether dealing with a perpetuation of the species, by crossing one

Addison, Johnson, Burke, and Davy, were all childless: few of them married. The grand-ilaughters of Shakspeare and Milton were the last of their respective line; and Sir Walter Scott, though he left forr children, is now nearly unrepresented in blood. 
variety with another, or by the more general custom of pairing animals of a like variety, maintains that success, in an eminent degree, has only occurred " in those instances in which the females were larger than in the usual proportion of females to males;" and hence urges a regard to that principle, as the most secure basis on which the operations of the breeder can be conducted. The reason he assigns in support of the practice is, "that the size of the foetus is generally in proportion to that of the male parent; and therefore, when the female parent is disproportionately small" (that is, when she holds the common relation to the male, in size, which we observe in Nature) "the quantity of nourishment is deficient, and her offspring has all the disproportions of a starveling." Admitting, for a moment, the correctness of Mr. Cline's opinion, "that the size of the fotus is generally in proportion to that of the male parent," it follows that its ultimate bulk must be regulated by the same law. If, then, we try to reverse the common order of things, and start with an unusually large cow, and a smart little bull, the produce, according to his showing, though well nourished throughout the period of utero-gestation, will be limited in size at birth, and in its ultimate growth, by the influence of the 
sire. Supposing such produce to be a cow calf, we may presume that it will not attain to his size, and that, therefore, it will be somewhat less than the female parent. To carry out Mr. Cline's principle, she should be put to a bull still smaller than her sire ; and thus we shall have a gradual declension in bulk, till, in a few generations, what might originally have been the largest variety of its species, will be scarcely seen to rival even sheep and pigs.

Earl Spencer, after dwelling on the qualifications essential to the constitution of the best class of males, adverts to the doctrine maintained by Mr. Cline, from which, however, he dissents, and for reasons which experience of no ordinary kind enables him to give. His lordship prefers to breed from large females; but observes that, if he do breed from one which he thinks too small, he puts to her the largest male of good shapc that he possesses. And in proof of the success resulting from such practice, he adduces an instance of a Smithfield prize ox, derived from his largest bull, in conjunction with a cow, so small, that he culled her after having bred that one calf. "My opinion, then," concludes his lordship, "the result of my own practical expericnce, is, that if a man considers the femalc animals which he 
possesses to be smaller than he wishes, he may safely put them to a male of large size, provided he is well-bred, of good quality, and well-shaped." Now if these two authorities are to be received in a sense precisely comporting with the language employed by them, it is obvious that one of them is in error. Whilst as yet the subject of breeding had been little benefited by the contributions of science, it was customary to include, amongst animals of a large and good class, those whose length and height greatly exceed the requirements of width; and to account but small others which should comprise the same bulk, under a different mode of arrangement. Even now, with many, does Virgil's autlority, in so far, obtain :

T'um longo nullus lateri modus ;

and had Mr. Cline's views on the relative merits of big and little bulls been less strenuously enforced, I should have thought that by the latter was intended to be understood compact malesbig ones in little room. But the pertinacity with which he adheres to his fanciful dogma, will justify no other conclusion than that he adopted little males in principle. His theory had reference, unquestionably, to the ease with which they may be prescrved in rude health: yet the argu- 
ment by which we thus establish the preference due to them, in a procreative sense, over those of a larger class, where food is scarce or of mean quality, tends with equal force to prove that a little cow, of good figure and constitution, may provide abundant nourishment, throughout the term of utero-gestation, for a calf, begotten of a large bull. It tends, also, further to prove the unsuitableness of little animals, in general, to land of better quality than is required to keep them in good store condition, whilst engaged in the capacity of breeding. For if, under the disadvantages attachable to scantiness of fare, they can maintain themselves in health, they must, of necessity, grow fat, when more liberally treated. Knowing this full well, I am at a loss to conceive why Mr. Cline should have insisted on the unconditional employment of little males. His zeal in the discountenance of extravagantly large ones, must have led him into an opposite error.

Est modus in rebus; sunt certi denique fines, Quos ultra, citraque nequit consistere rectum.

It is too much to say that " the size of the foetus is generally in proportion to that of the male parent." Its figure may be that of the male, or female parent, or of both, as they shall happen 
to have been affected towards each other in the reproductive passion : but the task of conducting the maintenance of the foetus, in utero, being exclusively that of the female, to her it must stand indebted for the progress it shall make whilst entrusted to her guardianship. And so far from the power of the female to supply her off-pring with nourishment being in proportion to her size, and to the power of nourishing herself from the excellence of her constitution, as taught by Mr. Cline, the reverse of this order of things, most commonly, obtains. The high-conditioned short-horn cow does not produce so heavy a calf, at birth, as the light-fleshed milking beast, whatever may be the character of the bull to which they shall respectively be put. The size of the new-born Alderney calf, again, is often truly astonishing, when viewed in relation to the insignificant source whence it has proceeded; and infants born of spare, but active, mothers far outweigh the chief of those which lie concealed, throughout the foetal term, in misappropriate stores of flesh and fat. Results thus differing from those which an $a$ priori argument might anticipate, are attributable to a law in the animal economy, which holds the constitution, when absorbed in its own nurture, comparatively irresponsible to other claims. To 
such influence may be ascribed the characteristic selfishness of males: for in proportion as they lustier grow than those whom they caress, do they revere themselves; and only, when o'erflowing with desire, betray the tender passion. So females, too, of masculine exterior, indulge but little sympathy with males. Their swelling forms engross their whole concern; and if they procreate, it is from sensuality alone. Hence do they claim the right to mould the embryo as they will; and having "formed and fashioned" it, in strict compliance with this law, they dole out nutriment so tardily, that when gestation ends, the foetus seems to have been abortively thrown off.

A recognition of this law is essential to a correct estimate of the operations of Nature; for only by reference to its authority can we reconcile the incompatibility of conflicting interests. The human female, whilst suckling, ceases to menstruate- the inferior animal, commonly, to entertain the male: and both, when loaded with condition, fail in the secretion of milk. With little trouble might I greatly swell the list of parallel instances, to prove that, in conformity with this principle, devotedness to one particular function, of necessity, involves the prejudice of others. 
A practical adoption of Mr. Cline's scheme is most properly observed when a farmer is removing from good to worse land. If he apply not himself to a reduction of the size of his cattle, under such circumstances, agreeably to the dictates of science, Nature will effect the change for him, in a manner less suited to his interest. Left wholly to her charge, the morbid laxity induced by insufficient nutriment, disqualifies the system for elaborating as before, the fortal rudiments. Strong branches grow not on distempered trunks: and those which now spring from the suffering herd, will represent their weakness in themselves. This, however, may be obviated by the timely introduction of a little bull. But not more advantageous is it to prefer him here, than to exchange him for a larger, if once more proceeding from a mean to better land. He who should take a hardy little race, adapted best to poor and hilly districts, down to creditable pasturage like that at Wiseton, would soon find their carcases augment beyond his wish. But not to dwell on that objection, it deserves to be considered that, for other reasons, are they out of place, where those of larger frame, and no less estimable quality will flourish. On every hand it is agreed that big good animals are more desirable than small and 
good; and since no further trouble is incurred in rearing great than small, the practice recommended by Earl Spencer, to conjoin with little cows, if such there be, a large and well-bred bull, is perfectly consistent with the rule I would suggest. No matter which their offspring may resemble : each being good, must surely good engender. And should it happen that they blend harmoniously in love, still no less worthy such embrace will be their offspring found.

A few words by way of induction, and I have done. To enter on a lengthened inquiry into the theory of generation would, I fear, be to perplex the reader with a multiplicity of conflicting statements and opinions from which little profit could be derived. The subject is confessedly one of the most intricate within the range of physio$\operatorname{logy}$; and I would not formally introduce it, but for the sake of rendering more intelligible some of the principles which I have already been attempting to establish. Long as the work of reproduction has been maintained amongst mankind, it has not until lately been determined to the satisfaction of those whom it most concerns, whether it be essential to impregnation, that the semen of the male and the rudiments of the female, be brought into actual contact. Many 
distinguished authorities have contended, because they could not discover semen in the cavity of the womb immediately after copulation, that it never enters that organ, and that conception must, therefore, be the result of a seminal aura or breath; whilst others of no less reputation have declared that they could not only detect semen within the womb, but along the Fallopian tubes, which furnish a communication between the upper and lateral part of the womb, on either side, and the ovaries, from which the fotal germ is eliminated. Hence have they insisted on the indispensableness of an admixture of the generative secretions to ensure conception. Not unfrequently, however, have the converts to this doctrine doubted its correctness. The rigid contraction of the uterine aperture in the unimpregnated state, and the difficulty of proving it to be otherwise at the moment of seminal emission, together with the many well-attested instances of impregnation having occurred, where the male fluid has been supposed to have passed no farther than the vulva, are circumstances that have contributed in no small degree to disturb their confidence. Thus hesitating to adopt even their own hypothesis unreservedly, they have tinctured, in like manner, subsidiary streams of information; and those 
whom we have been taught to regard as creditable authorities, are observed, on one page, to insist on the necessity of a close embrace of the sexes, and on another to dilate upon the superfluousness of the practice. It is hardly too much to say that neither ancient nor modern literature embodies a finer contribution to physiology than do the verses in which Virgil expresses his reasons for enjoining a spare diet and full work in the case of mares that are destined for breeding:

Hoc faciunt nimio ne luxu obtusior usus

Sit genitali arvo, et sulcos oblimet inertes:

Sed rapiat sitiens Venerem, interiúsque recondat.

Georg. iii. 135.

Lest genital inaptitude o'erpower

The native wish,--and mock the fruitless houl:

By art, induce them gladly to embrace

The pleasing earnest of a future race.*

Yet soon are we diverted from this maxim by a grave assurance, that so susceptible are mares of venereal excitement, as to have been known to conceive without intercourse with the other sex -an assertion which he qualifies, I admit, by limiting the outrage to one of false conception; and it is not difficult to discover that what he

* I an compelled to beg the realer's aeceptinee of this rendering. Sotheby has evidently declined to give the sense of the author, and Dryden is extravagantly verbose and obseene. 
intended to be construed as such, was nothing more than the mucus which occasionally escapes from mares, during the prevalence of extreme generative ardour, ${ }^{*}$ Nevertheless the entire passage went forth, subject to whatever application individual caprice or ingenuity might devise : and too soon was it observable that the luxuriances of poetry had been confined not to the legitimate muse; for Columella $\uparrow$ and Varro, + advancing on the authority of Virgil, boldly declared that, in Spain, mares had frequently been known to conceive and rear an offspring without masculine agency, but which were usually short-lived. Pliny too, with proverbial credulity, says it happens in Lusitania, near the city of Lisbon and the river Tagus, that mares, facing the west wind, conceive and bring fortl a living animal, of remarkable fleetness; but which survives not the third year. $\oint$ Fanciful as may appear to liave been the speculations of these writers, they can scarcely be said to exceed those which, under the speciousness of science, have been promulgated in comparatively modern times. Our illustrious country-

* Georg. iii. $269 . \quad$ Lib. vi. ca. $27 . \quad$ t Lib. ii. 1.

§ Constat in Lusitania circa Olisiponem oppidum et Tigum amuem equas Faronio flante observas animalem concipere spiritum, idque partum fieri, et gigni pernicissinum ita: sed triennium rite non excelere. Lib. viii. 47. 
man, Harvey, contended that the foetus was constituted of the female rudiments alone-a dogma warmly supported, as well, by Swammerdam; whilst Leeuwenhoeck, Hartsocher, and others, took up an opposite position, and argued that it was derived entirely from the male.

But I am already wandering from the path $\mathbf{I}$ had set out for myself; and will, therefore, retrace my steps in search of more available information. Dr. Blundell, a man whose genius and professional occupation admirably adapted him to the inquiry, instituted a series of experiments some years ago, with a view to decide the long agitated question, whether conception could occur, without an immediate contact of the male semen with the female rudiments. Rabbits were selected for the purpose of demonstration, on account of the disposition and capaciousness of their genital organs. The vagina of the doe, it should be premised, when full grown, is about three inches long. The wombs, in common with those of most omniparous animals, are two tubular organs of about the same length, when unimpregnated, and which communicate with the vagina by two distinct orifices, so completely independent of each other, that one may be removed with little or no injury to its fellow. The first set of experiments 
consisted in opening the bellies of several does, and dividing, transversely, one of the wombs, in each animal, at its juncture with the vagina. Notwithstanding the violence necessarily inflicted, most of them recovered, and eventually took the buck: but the lower or vaginal extremity of the severed wombs so effectually closed, as to forbid all seminal ingress. At different periods of uterogestation, the animals were destroyed, when they were found to have conceived on the uninterrupted, but not on the opposite, side. He next cut off the communication of both wombs with the vagina, by dividing the latter so high as to admit of subsequent intercourse with the male. All those which survived the operation, retained their sexual appetency, and were repeatedly put to the buck: yet none of them conceived. In both series of experiments, the ovaries, on either side, were highly excited by coition, as were also the Fallopian tubes. Graafian vesicles, as they are termed, were matured - their contents escaped - and evidence of the fact, in the establishment of little yellow bodies (corpora lutea), was distinctly traceable. The consequence of this descent of the female rudiments through the Fallopian tubes, into such of the wombs as were inaccessible to the semen, was an accumulation 
of fluid in them, proportioned to the vehemence of feminine desire, and the gratification afforded by interviews with the male. These circumstances were considered by Dr. Blundell, as indeed they deserved to be, in the light of abortive efforts of generation. To satisfy himself and others that the animals were not incapacitated for breeding by local violence and debility, consequent on the operations to which they were submitted, the doctor divided the vagina of two young does, and left the parts in apposition, that reunion might occur. This was soon effected, and, on being put to the male, they were both impregnated. He then, in several instances, operated on the wombs themselves, by making two, and sometimes three, transverse cuts nearly through, leaving only so much of their substance entire as to afford a reasonable hope of an adherence of the contiguous edges. Many subjects of this experiment died; but " the very first doe which recovered, produced no less than nine fotuses from her first intercourse with the male. Indeed so complete was the action of the uterus, that there was not one of the little masses of rudimental matter which it failed to mature; and it was found, on a careful comparison of the wombs with the ovaries, that the number of 
foetuses and corporea lutea was the same." These experiments are valuable, inasmuch as they prove, by direct and irrefragable evidence, that a commixture of the male semen and female rudiments is indispensable to impregnation:

\footnotetext{
Semper enim partus duplici de semine constat.

"For both must join, or nought can e'er ensue."
}

Such was the doctrine maintained by Epicurus and his followers; and it is not a little humiliating to find, after all the labour that has been devoted to the cultivation of this department, that we are scarcely in advance of the philosophy of generation, as taught in the "school of the garden" two thousand years ago.

Admitting the fact involved in Dr. Blundell's experiments to have been satisfactorily established, it becomes a question of no inconsiderable interest, by what means the semen arrives at its destination. That under circumstances most favourable to its transmission, it is somewhat sparingly entertained by the womb, few will pretend to deny. Nor is it necessary to prove more than that, however limited the supply, it does reach the womb; since it has long been agreed amongst physiologists that this fluid, in almost any divisible form, is enough for the accomplishment of its purpose. 
Against the argument that, during the height of venereal orgasm, the semen is ejaculated with sufficient force to explain the circumstance, applies this objection-that the relative position of the sexes is not always favourable to its reception; so that unless we could believe the uterus to be endowed with a larger share of prehension than the most sanguine advocate of its peculiar life (vita propria) would feel himself at liberty to avow, it would be difficult, in this stage of the inquiry, to resolve the question. To an inherent property of the vagina itself, analogous to the peristaltic motion of the intestines, must we look for collateral aid-a property greatly concerned, whether in the higher or lower orders of animals, in committing the semen to its impassioned recipient. And it is worthy, also, of remark, that reproductive intercourse, in the human subject (and I am equally certain that a like result occurs in brutes), is always accompanied with more or less feminine prostration, in some instances amounting pretty nearly to syncope. At that moment is it that the uterus imbibes the vital stream.* And since it is

* 'The effect of general relaxation on the previously rigid uterus is often strikingly exemplified in labour. 'The stomach, sympathizing with the womb, takes on nausen, and vomiting ensues. 'I'his diminishes fibrous irritability, and the "consummation devoutly to be wished" soon arrives. Hence the trite saying that sick labours are safe. Ordiuarily they are so. 
certain that faintness induces increased activity in the peristaltic motion of the intestines, it is perfectly allowable to suppose that an approximation to that state, in the pleasurable exercise of venery, may ellcourage the vaginal attribute of which I have spoken, together with that of the uterus itself.

Impressions thus eminently characteristic of the sex, are realized in a degree precisely corresponding to that in which feminine delicacy prevails. A refined sensibility-the usual accompaniment of slenderness and gracefulness of figure, participates most exquisitely in such enjoyment: and these are the subjects who, in the event of their marrying the object of their choice, bear children principally after the image of the sire. The more largely the nervous system is engrossed in the government of animal matter, the less susceptible is the individual of true feminine emotion: hence do those of a portly form care little for sexual commerce. If they possess an exuberance of nervous vigour, still do they not share the kindly feelings that belong to women of a different cast. Their character is then one of masculine enterprise; and but for their mammary developement and voice, we should be inclined to think them men. A constitutional rigidity of fibre, of which the uterine system equally partakes, defies 
all efforts at impregnation, unless previously subdued by physical labour and a relaxing diet. Then will the womb its pleasing task essay.* And with such treatment, I feel bound to confess they are the most valuable of all instruments in the perpetuation of their species. To deny that would be to reject the universal testimony of nature. But let me not here be misunderstood. I am speaking of robust, muscular, females that enjoy a sufficient amount of nervous power to keep themselves in good health and spirits. I have already shown that they look not on the other sex

* A question here very naturally arises-why females of abandoned charaeter, who answer not, physically, to the elass I have been describing, fail to conceive? It is thus to be aceounted for ; during the early part of their wretched career, they suffer from constant applehension of the evils resulting from impropriety; the first and clicf of which is-inupregnation. Fearso fully usurps the seat of that passion which presides under the blissful secnrity of marriage, as to preclude the possibility of coneeption. By and bye, another train of thought and aetion is established. She who has anxiously been waiting the fulfilinent of soine pledge, offered perhaps, impiously in the sight of henven, as the eondition on which her virtue was to be resigned, finds herself betrayed by her assoeiate; and yielding to the incitement of maddening revenge, she plunges into the very sink of pollution. And now no longer cherishing the hope of mutual love, she lontles the form she clasps, and thus sterility preserves. Sometimes it happens that such women terminate a course of profligacy in inarriage, and beeome the parents of families. I reeognize the in occasionally in my professional rounds; and an convinced that the barrenuess of prostitutes is attrihutable, not so inuch to pliysical defect of the ovaries or Fillopian tubes, as to that moral depravity, which is irreconcilable with affection for any individual objcet. 
as do the general class of females-that selfishness incites them to the soft embrace-and that, not only do their offspring, for the most part, inherit their constitutional properties, but that the prevailing sex is their own. A nicer adaptation of the nervous to the animal system than is observable in males of corresponding character (for it is notorious that females, cateris paribus, preserve greater temperateness of feeling and action than do those of the opposite sex), would seem to fit them most admirably for purposes of procreation, when they can be made available. My memory serves me with many instances that might be quoted by way of illustration, if the usages of society would admit of their introduction. One I will give from the history of my own family. My great-grandmother, in the line of my father, was a woman of this class, inheriting a huge and beautiful frame, with a proportionable amount of vital energy. Few men equalled her in physical strength; and tradition affirms that, when once insulted by the way, she seized the offender, and carrying him to a neighbouring river, threw him headlong in, at the imminent peril of his life. Her husband was an active man, but by no means comparable with her in natural endowments. 'Their sons partook of the mother's 
habit; and being derived from an indigent source, it was their lot to be employed as agricultural labourers. In this vocation they toiled industriously, lived contentedly, ate the "bread of carefulness," and died in a good old age-one, from whom I have the honour to have descended, numbering seventy, another ninety -four, and the last ninety-seven years. The succeeding generation was, perhaps, equally distinguished for native vigour; but one member appropriating his faculties to intellectual pursuits, ascended into a higher sphere of duty. His children may be said, with few exceptions, to maintain the nervous character of their ancestors, - some excelling in rude strength-others in mental exercises. And though the writer of this article has no pretensions to rank with either division, he can boast of a brother who, without any scholastic advantages beyond those in common, acquired a reputation at the University of Edinburgh, which has no parallel in the medical history of that institution. He obtained the first presidency, as it is termed, of every distinguished society accessible to students,wrote nine prize essays on literary and scientific subjects (most of them involving original discoveries in physiology), and when receiving the University gold medal, on his graduation, at 
the hands of the "Principal," was told that his thesis was considered by the Senate to be "not only superior to any given in that season, but to any ever presented to the faculty." Thus do we see the physical advantages attachable to this form of parentage, and the applicability of those who share in it, even to exalted purposes, under suitable culture. Our legislative assemblies are not without examples of a like kind, in the persons of some prominent members.

Amongst breeders it is a subject of much complaint, that good as the generality of their cow calves are, there rarely appears a first-rate bull. To obtain such, reference must be made to the nervous and muscular female-the acknowledged leader of the herd, or one after her disposition. If dependence be placed on a mild, benignant, dam, disappointment will most likely ensue. She seldom breeds a valuable bull: the former seldom fails. The mother of "Clarion," both of whose portraits are given in the treatise, published under the superintendence of the Society for the Diffusion of Useful Knowledge, appeared to me, by the loftiness of her bearing, as she walked along, on my visit to Wiseton in the autumn of 1835 , to be a beast of the class to which I now allude. And if my recollection serve me, she was the parent 
of "William" or "Wiseton," bulls that were held, at that time, in high esteem by Earl Spencer. Mr. Wilkinson's late Hebe was a cow of this description; and whilst in his possession, she bred two excellent bulls. And an animal he bought out of Durham some years ago (Will Honeycomb), which I believe to be the best I have ever seen of any variety, is indebted for his distinction to a dam of similar character. Virgil, therefore, though somewhat unfortunate in detail, was correct in principle, when advising a selection of masculine females, as security for a vigorous offspring. The original passage, for its classical beauty, together with the spirited translation of Sotheby, I will subjoin :

Seu quis, Olimpiacæ miratus præınia palnææ,

Pascit equos, seu quis fortes ad aratra juvencos;

Corpora præcipue matrum legat. Optima torre

Forma bovis, cui turpe eaput, eui plurima cervix,

Fit erurum tenus à inento palearia pendent.

'Tum longo nullus lateri modus : omnia magna:

Pes etiam, et eamulis hirtæ sub eornibus aures.

Nee mihi displieeat maculis insignis et albo:

Aut juga detrectans, interdunque aspera cornu,

Et fateiem tauro proprior: quæque ardua tota,

Et gradiens imâ verrit vestigia eaudh.

Georg. iii. 49.

Who for th' Olympian palin the courser rcars,

Or breeds, to bear the yoke, resistless stcers,

With prescient care the destined mother trace,

$\triangle$ nd formed like her expect the promised race. 
If her large front and neck vast strength denote;

If on her knee the pendulous dewlap float;

If curling horns their crescent inward bend, And bristly hairs beneath the ear defend;

If lengthening flanks to boundless measure spread;

If broad her foot, and bold her bull-like head;

If snowy spots lier mottled body stain,

And her indignant brow the yoke disdain,

With tail wide sweeping, as she stalks, the dews;

Thus, lofty, large, and long, the mother choose.

Resuming the more immediate subject of generation, it remains for me now, in as popular a form as delicacy will permit, to contemplate the progressive evolution of the foetus. In the absence of precise information on this head, we should be at no loss to conceive the probability that, with products designed by Nature to constitute the basis of animal developement, there would be identified a considerable degree of vitality. Both the semen and female rudiments have been presumed to abound with organic molecules; and microscopical research having confirmed the propriety of such belief in respect of the former, there can be little reason to doubt (since the ovaries, from which the female rudiments proceed, hold the same relation to the female as do the testicles to the opposite sex) that a like vital property belongs also to the latter. 'To ordinary observation, neither of them affords any indication of the pre- 
sence of animal life : but at an early period of utero-gestation, it is found that what had previously existed in the form of insensate matter has undergone a very sensible change. A rudimental heart, incited to action by inherent irritability, is now discoverable; and scarcely has pulsation commenced before the stimulus, by which it is maintained, finds a repertory in the growth of the brain and spinal cord. The most essential process in the animal economy - that of circulation, having been thus instituted, fresh accessions of matter soon follow, first in the neighbourhood of the heart, and radiating thence, as it were, to the extremities. For the trunk, it is to be remembered, acquires a somewhat definite character, before the limbs, which pullulate from it like radicles from the parent seed, begin to appear. These operations proceed with a rapidity proportioned to the length of time occupied in the entire work of utero-gestation, and are, therefore, longer delayed in the human subject than in most inferior animals. But it never can be too strongly impressed on the minds of those who take an interest in the breeding of cattle, that the growth of parts most remote from the parent organ (the heart) is conducted with freedom, in the inverse ratio to the bulk of the animal base. So that 
if the germ be large, as where reproduction occurs between a pair, one of which, at least, is of full habit (in conformity with a law already explained, and whose dominion involves even the nascent embryo), the formative efforts of Nature are too intently occupied, in the first instance, to be easily diverted by consecutive claims. Hence are the extremities of large bodied animals shorter than those of a slender figure, and vice versa. This must have been Mr. Cline's view when contending that, by his method of crossing a large female with a small male, "the lungs and heart become proportionately larger, in consequence of a peculiarity in the circulation of the foetus, which causes a larger proportion of the blood, under such circumstances, to be distributed to the lungs than to the other parts of the body ; and as the shape and size of the chest depend upon that of the lungs, hence arises the remarkably large chest which is produced," \&c.

According to Lucretius, it would seem that some of the principles illustrated in the preceding pages constituted part of the Epicurean system of philosophy. The chief of them will be found in a passage which $I$ will here transcribe, for the sake of showing in what respect such doctrine differs from my own : 
Et couniscendo quom semine forte virili

Femina vìn vicit subitî vi, couripuitque;

Tum similcs matrum inaterno semine fiunt:

Ut patribus patrio: sed, quos utriusque figuræ

Esse vides juxtim, miscenteis volta parentum,

Corpore de patrio ac materno sanguine crescunt,

Semina quora, Vcneris stimulis excita per artus,

Obria conflixit conspirans mutuns ardor;

Et neque utrum superavit eorum, ncc supcratum est.

Fit quoque, ut interdum similcs exsistere a vorum

Possint, et referant proarorum sæpc figuras;

Proptcreat, quia multa modis primordia multis

Mixta suo cclant in corpore sæpe parentes,

Quæ patribus patres tradunt a stirpc profecta.

Inde Venus variâ producit sortc figuras;

Majorumque refert voltus, vocesque, comasque:

Quandoquideu nihilo minus hæc de seminc certo

Fiunt, quim facies, et corpora, membraque, nobis.

Et mulicbre oritur patrio de scmine seclum;

Maternoque mares exsistunt corpore cretei.

Semper enim partus duplici de semine constat:

Atque utri simile cst inagis id, quodquomque creatur,

Ejus habet plus parte æquâ, quod cerncre possis,

Sive virûm suboles, sire est inuliebris origo.

De Rer. Nat. iv. 1202.

If, when the malc his genial tide protrudes, The panting female deep lier breath retract, Transported most, the racc produced will, then, From female stores prove fcmale, if rcverscd, From stores paternal, malc. But when the form

Blends both its pitrents' features, it itscends

From equal powers of each; the warm embrace Rousing alike, througlı eitch conflicting frame, 'The secds of latent life, in scale, so nice, That neither conquers, nor to conquest yields.

Oft view we, too, the living lines portrayed

of ancestors remotc; for various sceds, 
Commingled various, through the parent frame Lurk, whieh from race to race preserve entire 'The form, the features of th' anterior stoek.

Diversely sueh the power creative blends;

Whenee oft the voice revives, the hair, the hue, The full eomplexion of the race deceased:

For these as sure from seeds defined aseend As e'en the face, the body, or the limbs.

Then, too, though male the foctus, female stores Aid the production; while, if female formed, The tide paternal mixes in the make;

For both must join, or nought can e'er ensue.

But obvious this, that where the semblanee more

Inelines to either, the prevailing sex

Chief lent the seeds of life, and reared complete

The virgin embryo, or incipient man.

GOOD.

Unfortunately, one fundamental error-that of failing to recognize the difference between absolute and relative pleasure, pervades this system. If, in reproductive intercourse, says Lucretius, the female be

Transported most, the race produeed will, then,

From female stores prove female, if reversed,

From stores paterual, male.

Now it cannot, for a moment, be doubted, that a preponderance of bliss is the inheritance of those individuals who, whether male or female, possess the greatest share of sensibility. And yet they are seldom personally represented in the next succeeding generation. In character and constitutional predisposition, they are intimately iden- 
tified with their offspring; but not commonly in physical arrangement, except in so far as some local resemblance, of comparative unimportance, is concerned. Having naturally a high tone of moral feeling, they are rarely induced to marry other than those whom they tenderly regard. And then the most exquisite delight is their'snot simply because they are exalted to a participation in pleasures which the law of celibacy had, till now, proscribed; but because their enjoyment involves the embrace of objects whom they cherish beyond every earthly consideration besides. That which affords them inexpressible felicity, under these circumstances, would be a source of insurmountable grief, if conducted with any but their chosen lovers; in evidence of which, we have the affecting story of Lucretia, kinswoman of the Roman poet and philosopher, before us. Yet do I repeat that, notwithstanding the rapture implied in such devotedness, people of this class are seldom recognized in the persons of their children. Various are the suggestions that arise, in attempting an immediate explanation of the fact. We may suppose that, as sensibility tends to impair nervous efficiency, precedence (in a work confessedly requiring an exercise of vital energy) naturally and necessarily devolves on the party 
whom it shall least incapacitate. But this is to admit that the ruling parent is, in a general sense, the more hardy and efficient instrument of the two; whilst observation tells us that many a seeming nerveless woman, whose form consumes so fast the feeble life allotted her, that not a thought has she, save how she best may gratify her soul, conceives a numerous family in her own likeness, and that too, when justly charging their paternity on one of incomparably greater vigour. So oft, again, conjoined with sprightly women, are men of dull and churlish disposition seen, whom love can scarcely rouse to charitable intercourse ; and yet whose children, "true to Nature's die," their veritable form and features blend. Another theory, and one more reconcilable with truth, is to maintain that love, which, in its purest form, subdues whatever heart it reaches, binds its votary to defer, no less in reproductive, than in social, intercourse; and that as, obviously, in outward things, the purport of such deference is to assign dominion to another, so in the subtler exercise of love, a corresponding tendency pre. vails. Whatever may be the rationale adopted, of this I am convinced, that in proportion to the intensity of regard entertained by a woman for her husband, is the prevalence of his likeness in the 
offspring-unless he happen to requite her love by an equal amount of tenderness. Then do their children happily combine the physical characteristics of them both: and what is of infinitely greater moment, as well in reference to time as to eternity, they constitute, in a moral sense, the best of all that is human. I have known people, in some instances, to marry, where the only incentive to union has obviously been a mutual attachment.* A few of the parties have had but crude ideas of the Christian dispensation: yet in every case where impregnation has followed, have their children been distinguished for their virtues. Would that all who plead a special interest in Christianity were actuated by motives equally creditable; -we should not so commonly as now be heard to exclaim, on observing the outrages committed by the descendants of avowedly religious parents, how strange! that they who have had continually before them a good example, in the persons of both father and

- Let me not here be supposed to include all the poor senseless, dissipated, beings who may be thoight, by careless observers, to marry from virtuous motives, because the imputation of avarice cannot apply to them. The inducements to marriage are probably as various as the modifications of which our passions are susceptible; and there is too much reason to fear that, if the secrets of all hearts could be explored, a very inconsiderable portion of the community, in any grade of life, would be found to engage in this "holy estate" from pure and reciprocal affection. 
mother, should be found thus insensible to the requirements of morality; whilst the children of those, again, who have scarcely seemed to recognize the doctrine of future rewards and punishments, should occasionally be seen to adorn whatever rank they move in.

If, for the sake of additional argument, we pursue the history of a highly sensitive femalc, through a long series of unrelenting abuse, incurred not unfrequently in marriage, until the source whence it proceeds is looked upon with comparative indifference; or mark the widow of a man who, even in death, retains her heart in thraldom, affianced, from motives of expediency, to another, we shall find that, though participating but faintly in joys that once enraptured her, the children she may now conceive will be more immediately identified with her in person, than those she previously had borne. Hence do I maintain that it is only by reference to the generative passion, in a relative sense, that we can predetermine the physical and moral qualifications of the issue of any pair. Does pure and unrequited love incline the heart of one towards another? Then will the personal character of the latter be discoverable in their children, with just so much of human sympathy as shall have been engendered by the affec- 
tionate disposition of the former. Do they regard each other with mutual tenderness? Then will the physical and moral attributes of both be shared in tlie constitution of all that humanity can desire. Are they led by animal instinct alone to propagate their kind? Again is the form and figure of each parent viewed in the rising stock: but, in a moral sense, I hold that they who are thus conceived, stand little better than as antitypes of hell! I will not deny the power of the gospel to redeem them : nevertheless do I believe that, as ordinarily administered, it seldom does. Having no greater amount of sensibility than the beast that perishes, they are, for the most part, inaccessible to its influence. No blush extends its mantling grace to them,-no tear illumes the portals of the soul,- - the smile of infancy, the pride of youth, the joylessness of age, educe no sympathies,-alike despised and dreaded do they live, and steeped in self-creating agony they die.

Qualified in a sense which the preceding reflections suggest, the doctrine of Lucretius is reconcilable with that which multiplied observation has led me to entertain. If it be insisted that, when the female is "transported most," by virtue of her greater regard for the object of her embrace than is conceived by him for her, "the race produced 
will, then, from female stores, prove female ;" or, taking up another and yet more defensible position of the author, inasmuch as it contends not, necessarily, for a reproduction of the sex, along with that of like form and features-I would say, if it be insisted that, when the female is "transported most," by reason of her greater affection for the opposite party than is shared by her in return, the physical character of the offspring is, for the most part, that of the mother, the argument is negatived by induction, whether in reference to man or brute. But if it be alleged that, when the female participates most in abstract pleasure, the product resembles her,-and vice versa, the theory comports with the universal testimony of nature : and in that sense I heartily concur with Lucretius in his summary of the Epicurean doctrine. 





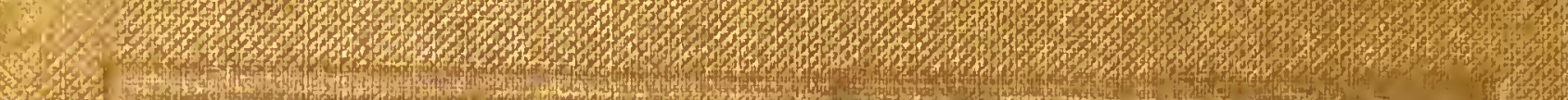

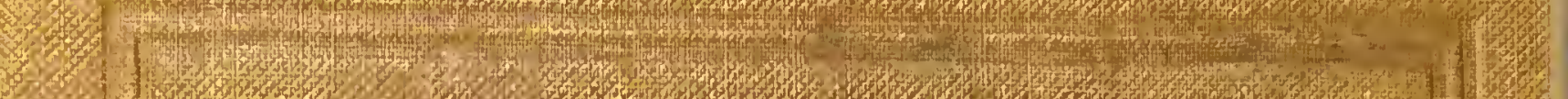

